
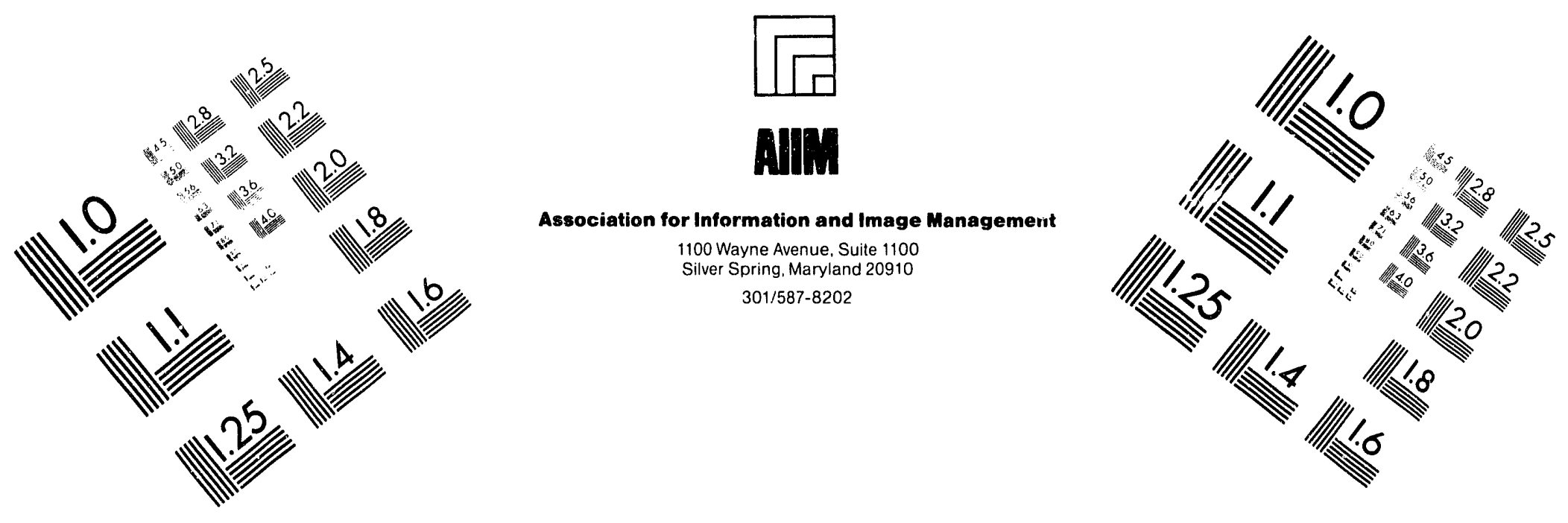

\title{
Centimeter
}

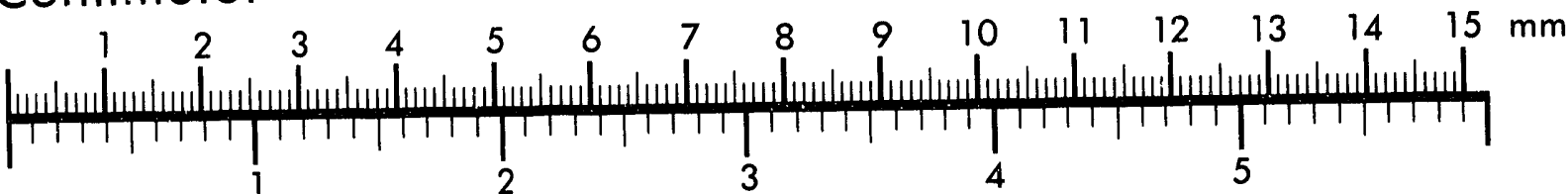
Inches
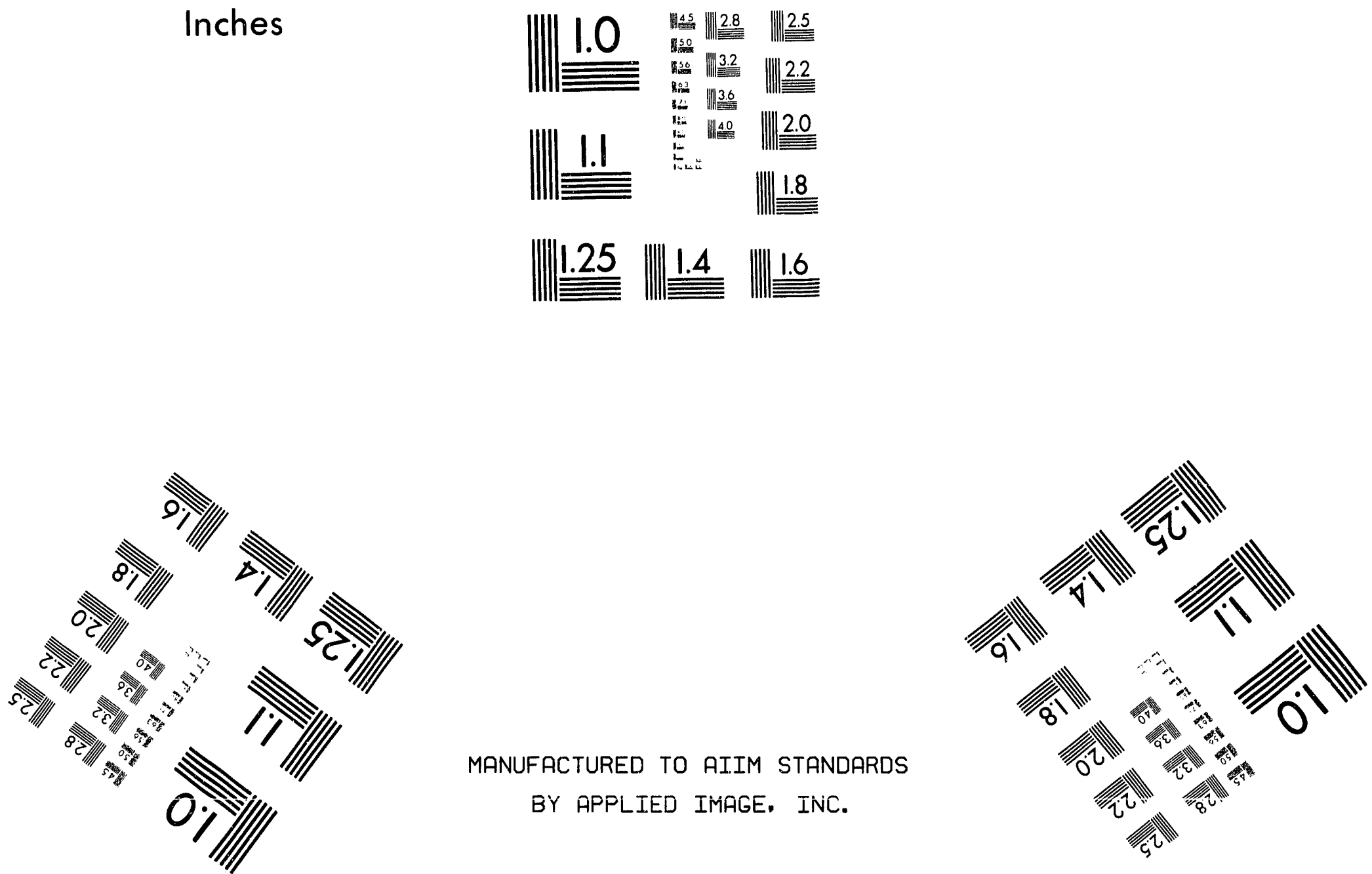

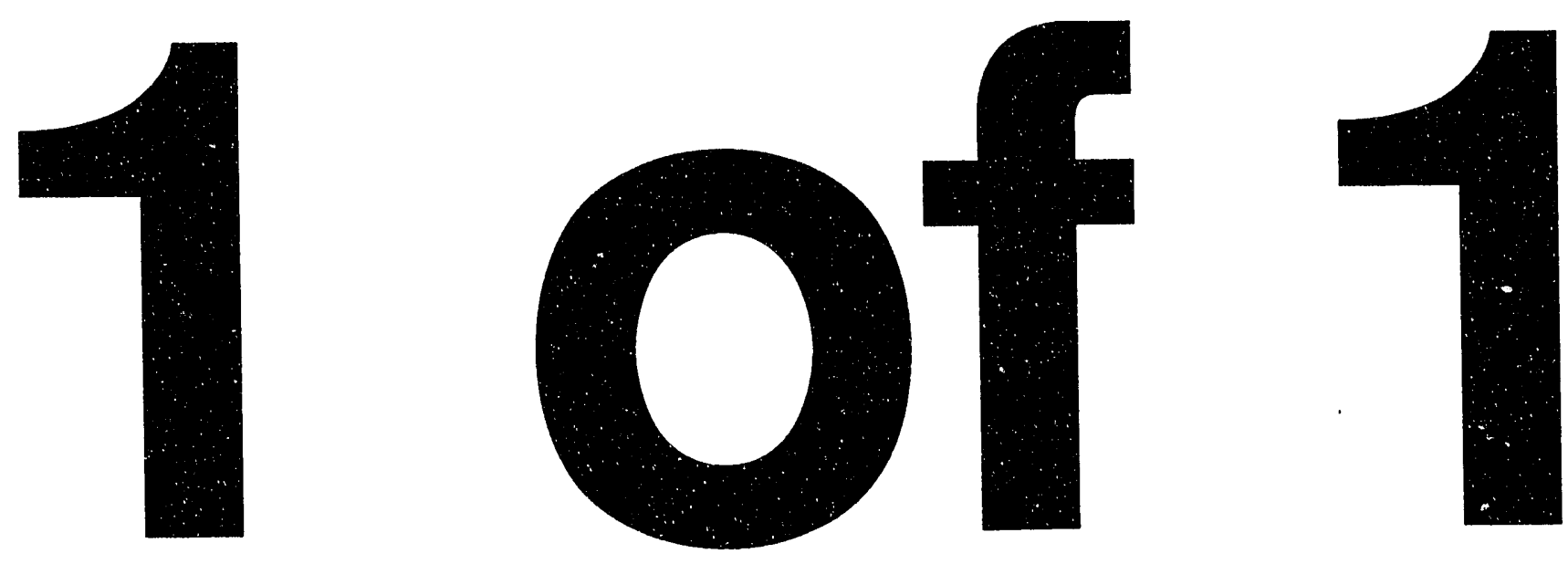


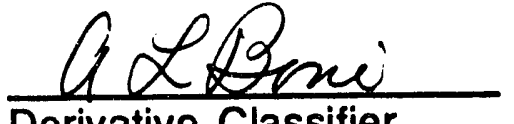

Derivative Classifier

\section{ASSESSMENT OF RADIOCARBON IN THE SAVANNAH RIVER SITE ENVIRONMENT(U)}

W. H. Carlton

A. G. Evans

C. F. Murphy, Jr.

D. M. Tuck

Approved by

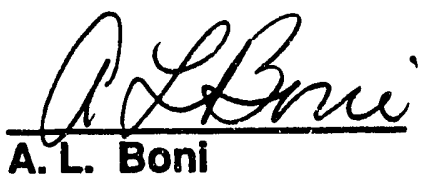

Research Manager

Environmental Technology Section

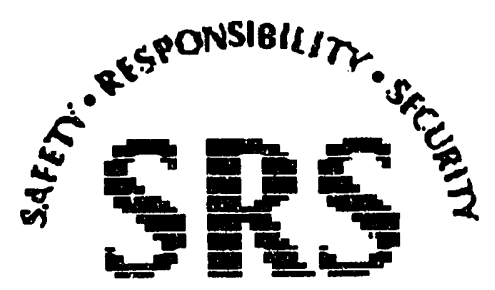

SAVANNAH RIVER SITE

Westinghouse Savannah River Company

Savannah River Technology Center

Alken, SC 29808 


\section{DISCLAIMER}

This report was prepared as an account of work sponsored by an agency of the United States, Government. Neither the United States Government nor any agency thereof, nor any of their employees, makes any warranty, express or implied, or assumes any legal liability or responsibility for the accuracy, completeness, or usefulness of any information, apparatu". product, or process disclosed, or represents that its use would not infringe privately owned rights. Reference herein to any specific commercial product, process, or service by trade name, trademark, manufacturer, or otherwise does not necessarily constitute or imply its endorsement, recommendation, or favoring by the United States Government or any agency thereof. The views and opinions of authors expressed herein do not necessarily state or reflect those of the United States Government or any agency thereof.

This report has been reproduced directly from the best available copy.

Available to DOE and DOE contractors from the Office of Scientific and Technical Information, P.O. Box 62, Oak Ridge, TN 37831; prices available from (615) 576-8401, FTS 626-8401.

Available to the public from the National Technical Information Service, U.S. Department of Commerce, 5285 Port Royal Rd., Springfield, VA 22161.

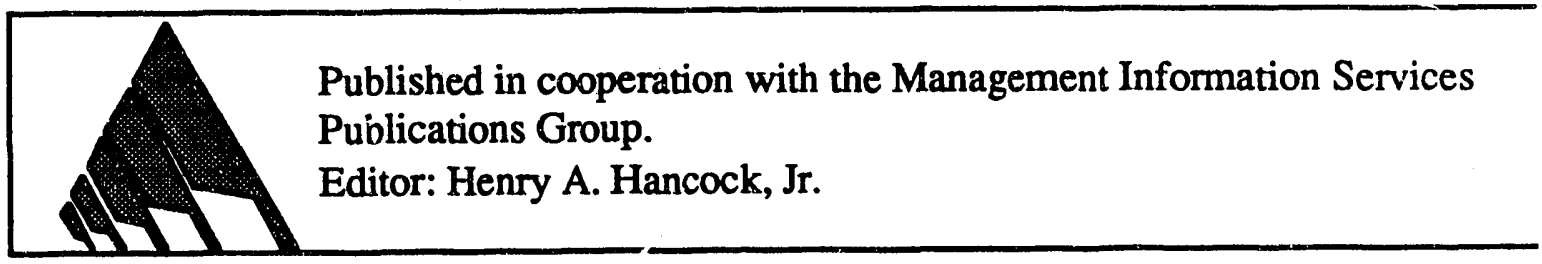




\section{Executive Summary}

Assessment of Radiocarbon in the Savannah River Site Environment is published as a part of the Radiological Assessment Program. It is the seventh in a series of eight documents on individual radioisotopes released to the environment as a result of Savannah River Site (SRS) operations. The earlier documents describe the environmental consequences of tritium, iodine, uranium, cesium, plutonium, and strontium. A document on technetium will be published in the future. These are living documents and current plans call for revising and updating each one on a two-year schedule.

The interaction of cosmic rays with the upper atmosphere produces ${ }^{14} \mathrm{C}$. In addition, ${ }^{14} \mathrm{C}$ has been produced by nuclear device testing and to a much lesser degree by the operation of nuclear reactors.

During the operation of five production reactors ${ }^{14} \mathrm{C}$ has been produced at SRS Approximately 3000 curies have been released to the atmosphere but there are no recorded releases to surface waters. Once released, the ${ }^{14} \mathrm{C}$ joins the carbon cycle and $a$ portion enters the food chain.

The overall radiological impact of SRS releases on the offsite maximum individual can be characterized by a dose of 1.1 mrem, compared with a dose of 12,960 mrem from nonSRS sources during the same period of time. Releases of ${ }^{14} \mathrm{C}$ have resulted in a negligible risk to the environment and the population it supports.

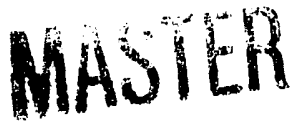


This page intentionally left blank.

Executive Summary -ii 


\section{CONTENTS}

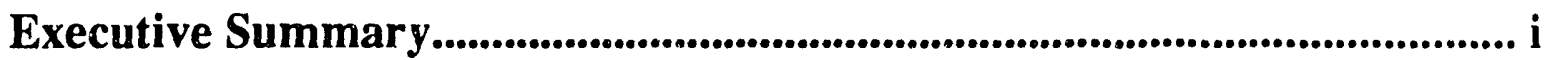

Chapter 1. Introduction ..............................................................................1

Radiocarbon in the Global Environment...............................................................................................1-3

Radiocarbon in Regional Environments........................................................................................ 1-3

Radiocarbon in the Savannah River Site Environment .............................................................1-3

References .................................................................................................................................................... 1.4

\section{Chapter 2. Origin and Disposition of Carbon at the} Savannah River Site ....................................................................2-1

Origin of Radiocarbon at the Savannah River Site ......................................................................2-3

Radiocarbon Produced in the Reactor Moderator 2-3

Radiocarbon in Fuel and Targets Irradiated in Production Reactors................................ 2.4

Radiocarbon Purchased Offsite ...............................................................................................................2-4

Radiocarbon in Certain Fuels Irradiated Offsite.....................................................................2-4

Radiocarbon in Fuel and Targets Irradiated in Test Reactors............................................ 2-4

Neutron Activation Analysis Samples ............................................................................................ 2-5

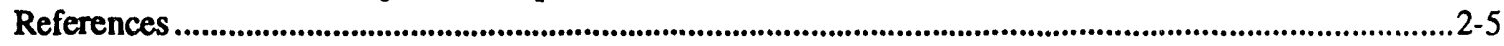

\section{Chapter 3. Releases and Stored Inventories of Radiocarbon at the} Savannah River Site ........................................................................3-1

Reactor Facilities ................................................................................................................. 3-3

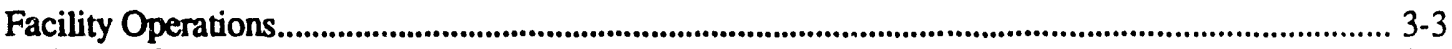

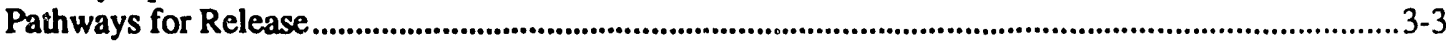

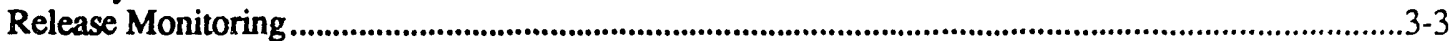

History of Releases ................................................................................................................................ 3-4

Separations and Liquid Waste Facilities.......................................................................................... 3-6

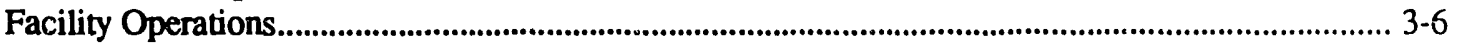

Pathways for Release ................................................................................................................................... 3-6

Release Monitoring ................................................................................................................................... 3-6

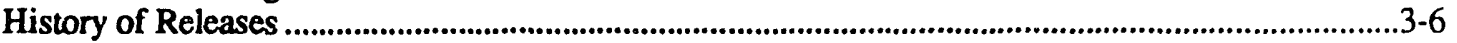

Solid Waste Disposal Facility .................................................................................................................. 3-7

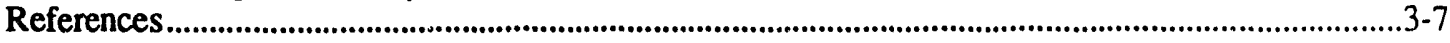

\section{Chapter 4. Radiocarbon Concentrations and}

Transport Mechanisms....................................................................... 4-1

Atmospheric Concentration and Transport ....................................................................... 4-3 
Surface Water Transport ..................................................................................................... 4-4

Groundwater Concentrations and Transport ........................................................................... 4-4

The Savannah River Site Groundwater System ...................................................................................... 4-4

Radiocarbon in the Savannah River Site Groundwater........................................................4-6

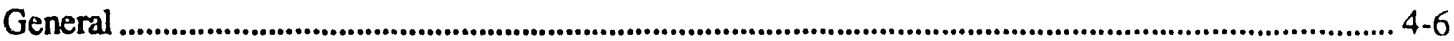

General Separation Area Basins ...................................................................... 4-7

F-Area Seepage Basins.................................................................................................. 4-7

H-Area Seepage Basins ............................................................................................ 4-8

Solid Waste Disposal Facility .............................................................................................................. 4-10

Summary .............................................................................................................................................................. 4-10

References ............................................................................................................................................................ 4-12

\section{Chapter 5. Assessment of Dose/Risk from the Savannah River Site} Radiocarbon Releases .................................................................. 5-1

Relationship of Dose to Risk and Health Effects............................................................ 5-3

Ionizing Radiation ..................................................................................................................................... 5-3

Cancer Risk Estimates................................................................................................................................... 5-3

Radiocarbon Exposure and Dose to Man ....................................................................................5-3

Distribution and Retention of Carbon in the Human Body........................................................................ 5-3

Radiocarbon Dosimetry.................................................................................................................................... 5-3

Models of Radiocarbon Transport and Dose............................................................................ 5-4

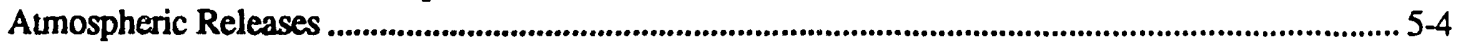

Modeling Atmospheric Dispersion of Radioactive Releases...................................................................... 5-4

Validation of Transport Models Using Monitoring Data .................................................... 5-6

Atmospheric Releases ............................................................................................................................................ 5-6

Impact of the Savannah River Site Radiocarbon Releases on the Offsite Population... 5-6

Doses from Atmospheric Releases............................................................................................................ 5-6

Doses from Liquid Releases .............................................................................................................. 5-8

Comparisons of Radiocarbon Doses Near the Savannah River Site with

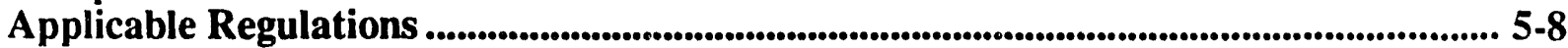

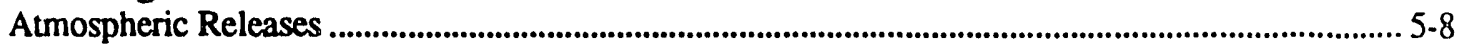

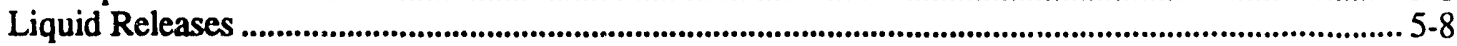

Summary of Dosimetric Impacts ................................................................................................................. 5-8

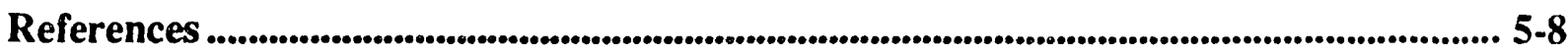




\section{List of Tables}

2-1. The Savannah River Site areas which had the potential to release carbon...............................................2-2

3-1. Atmospheric radiocarbon releases from reactor areas, curies .....................................................................3-5

3-2. Atmospheric radiocarbon releases from Separations areas, curies.............................................................3-8

4-1. Estimation of the atmospheric concentration of radiocarbon in the vicinity of the Savannah River Site relative to background radiocarbon ...............................................................................4-3

4-2. Ranges and average concentrations of radiocarbon in F-Area wells with radiocarbon levels above the detection limit ......................................................................................................4-8

4-3. Ranges and average concentrations of radioacarbon in H-Area wells with radiocarbon levels above the detection limit ...........................................................................................4-10

5-1. Site-specific parameters for atmospheric releases................................................................................... 5-5

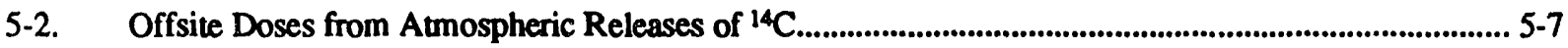

\section{List of Figures}

2.1 The Savannah River Site areas which had the potential to release carbon................................................ 2-2

3.1. The Savannah River Site operating areas ................................................................................................... 3-2

3.2. Radiocarbon releases to atmosphere, $C$ Area ....................................................................................... $3-4$

3.3. Radiocarbon releases to atmosphere, $\mathrm{K}$ Area ...........................................................................................3-4

3.4. Radiocarbon releases to atmosphere, $L$ Area .........................................................................................3-4

3.5. Radiocarbon releases to atmosphere, P Area................................................................................................. 3-4

3.6. Radiocarbon releases to atmosphere, $R$ Area ................................................................................................... 3-4

3.7. Radiocarbon releases to atmosphere, F Area................................................................................................... 3-7

3.8. Radiocarbon releases to atmosphere, $\mathrm{H}$ Area ...........................................................................................3-7

4.1. Stratigraphic and hydrostratigraphic nomenclature used on the Savannah River Site ............................4-5

4.2. Hydraulic head differences across confining units near the cretaceous-tertiary boundary..................... 4-6

4.3. Location map of General Separations Area .........................................................................................................4-7

4.4. Groundwater monitoring near F-Area seepage basins..................................................................................... 4-9

4.5. Groundwater monitoring near H-Area seepage basins ........................................................................ 4-11

5.1 Simplified pathways between radioactive materials release to the atmosphere and man........................ 5-4 
This page intentionally left blank. 


\section{Chapter 1. Introduction}

Carbon is an element essential to life on earth. Man-made radioactive isotopes of carbon, if introduced into the global and regional environments, eventually will reach humans via the food chain. Thus, man-made radioactive isotopes of carbon will contribute to the radiation dose that humans receive from all sources. 
This page intentionally left blank. 


\section{Radiocarbon in the Global Environment}

Radioactive isotopes of carbon, collectively known as radiocarbon, exist in nature at low but detectable levels. The only radioisotope of carbon with a halflife greater than a few minutes is ${ }^{14} \mathrm{C}$, with a half-life of 5730 years. ${ }^{12} \mathrm{C}$ and ${ }^{13} \mathrm{C}$ are stable isotopes; ${ }^{12} \mathrm{C}$ is predominant on earth, with a natural abundance of 98.89\%.

When a nitrogen nucleus captures a neutron and emits a proton (an $n, p$ reaction) ${ }^{14} \mathrm{C}$ is produced in nature primarily in the upper atmosphere (Libby, 1952). Prior to $1954,{ }^{14} \mathrm{C}$ existed in secular equilibrium in the biosphere at a concentration of 7.5 $\pm 2.7 \mathrm{pCi}{ }^{14} \mathrm{C} / \mathrm{g} \mathrm{C}$ (Eisenbud, 1987). The average production rate of ${ }^{14} \mathrm{C}$ is $0.038 \mathrm{MCi} / \mathrm{yr}$ which leads to a steady-state atmospheric inventory of $3.8 \mathrm{MCi}$ (NCRP, 1985). The ${ }^{14} \mathrm{C}$ becomes carbon dioxide in the atmosphere and is assimilated into biological systems in the same manner as stable carbon. When an orgarism dies, the amount of ${ }^{14} \mathrm{C}$ slowly decreases and carbon dating (the ratio of ${ }^{14} \mathrm{C}$ to stable carbon) can be used to estimate the time of death (Eisenbud, 1987).

During the atmospheric testing of nuclear devices ${ }^{14} \mathrm{C}$ also was produced by the ${ }^{14} \mathrm{~N}(n, p){ }^{14} \mathrm{C}$ reaction. By the end of 1967 , the tropospheric ${ }^{14} \mathrm{C}$ content had increased about $60 \%$ above natural levels in the northern hemisphere and a little less in the southern hemisphere (Eisenbud, 1987). The dose equivalent from ${ }^{14} \mathrm{C}$ in fallout reached a peak of $0.96 \mathrm{mrem} / \mathrm{yr}$ in 1965 and diminished to $0.37 \mathrm{mrem} / \mathrm{yr}$ by 1984 (NCRP, 1985).
It has been estimated that $9.6 \mathrm{MCi}$ of ${ }^{14} \mathrm{C}$ was injected into the atmosphere as a resul: of nuclear testing between 1945 and 1980. In addition, power reactors released an estimated $0.235 \mathrm{MCi}$ through 1990 (NCRP, 1985).

During the years prior to atmospheric testing, the concentration of ${ }^{14} \mathrm{C}$ in the atmosphere declined by some $25 \%$. This was due to the increased use of fossil fuels, such as oil and coal, which injected large quantities of stable carbon into the atmosphere, thereby diluting the ${ }^{14} \mathrm{C}$.

Increased use of fossil fuels may well lead to a greenhouse effect and warming of the earth, but the dose to man from ${ }^{14} \mathrm{C}$ in the environment will decline.

Radiocarbon exists primarily as a gas and remains distributed in the stratosphere, troposphere, biosphere, and surface ocean waters for extended periods of time. Transfer among the surface components takes place with time constants on the order of a few years, but transfer to the deep oceans proceeds more slowly. A stratospheric injection of ${ }^{14} \mathrm{C}$ will reach equilibrium in the biosphere after a few years, then decrease slowly at a rate determined by transfer of the ${ }^{14} \mathrm{C}$ to deep ocean water and possibly humus (NCRP, 1985).

\section{Radiocarbon in Regional Environments}

Since ${ }^{14} \mathrm{C}$ is released into the atmosphere from nuclear device tests and nuclear reactors, concentrations near a release point will be elevated temporarily but will rapidly approach the global average as the carbon is transported and mixed in the atmosphere.

\section{Radiocarbon in the Savannah River Site Environment}

The Savannah River Site (SRS) reactors produce ${ }^{14} \mathrm{C}$ and it is released into the atmosphere from both the reactors and the separation facilities. From 1955 through 1989 , approximately $0.003 \mathrm{MCi}$ of ${ }^{14} \mathrm{C}$ was released. 59\% from the reactors and $41 \%$ from separation facilities (Cummins et al., 1991). 


\section{References}

Cummins, C. L., C. S. Hetrick, and D. K. Martin, 1991, Radioactive Releases at the Savannah River Site 1954-1989, WSRC-RP-91-684, Westinghouse Savannah River Company, Savannah River Site, Aiken, SC 29808.

Eisenbud, M.. 1987, Environmental Radioactivity from Natural, Industrial and Military Sources, Third Edition, Academic Press, Orlando, FL.
Libby, W. F., 1952, Radiocarbon Dating, University of Chicago Press, Chicago, II.

NCRP, 1985, National Council on Radiath:n Protection and Measurements, Carbon-14 in the Environment, NCRP Report No. 81, Bethesda, MD. 


\section{Chapter 2.}

\section{Origin and Disposition of Carbon at the Savannah River Site}

This chapter gives a general overview of the origin and disposition of radiocarbon at the Savannah River Site (SRS) under normal operating conditions. The locations of the SRS areas which had the potential to release carbon are shown in Figure 2.1. The releases of ${ }^{14} \mathrm{C}$ occurred during the years of reactor and chemical separation facility operation. 
Figure 2.I. The Savannah River Site areas which had the potential to release carbon

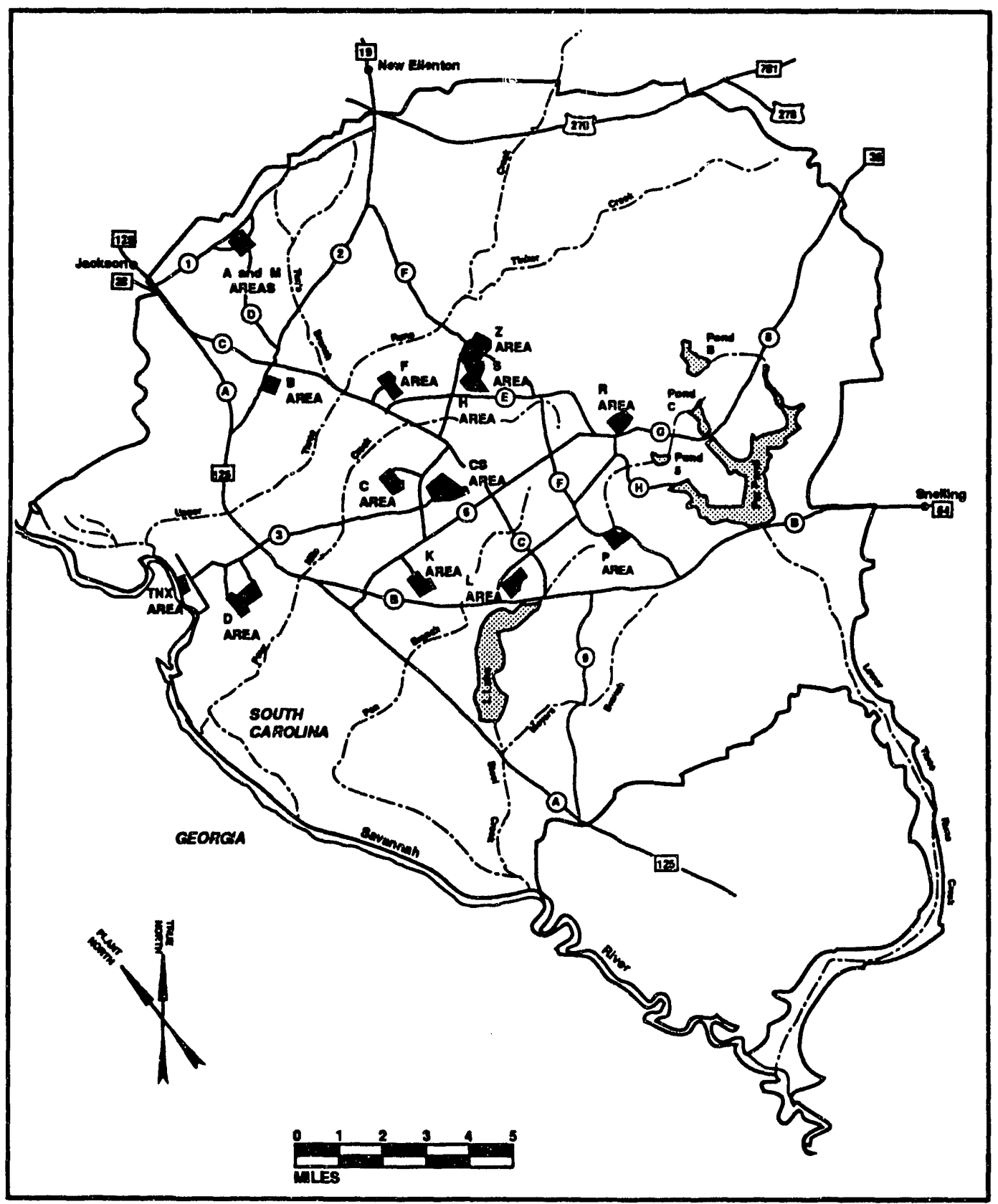




\section{Origin of Radiocarbon at the Savannah River Site}

The SRS produced ${ }^{14} \mathrm{C}$ by various reactions in the fuel, moderator, and core construction materials in five production reactors. The mechanisms include neutron-induced reactions $[(n, p) ;(n, \alpha) ;$ and $(n, \gamma)]$ and ternary fission (Hayes and MacMurdo, 1977). A summary of the mechanisms is given in Table 2-1. The $(n, p)$ reaction produces ${ }^{14} \mathrm{C}$ by reaction of neutrons with ${ }^{14} \mathrm{~N}$. Nitrogen occurs as an impurity in the fuel, as dissolved gas, as nitric acid, as ammonium hydroxide (used for $\mathrm{pH}$ control purposes in the moderator), and as an impurity in the core material. Small quantities of ${ }^{14} \mathrm{C}$ also are produced by the $(n, p)$ reaction with nitrogen in the air in the annular cavity outside the reactor tank. The $(n, \alpha)$ reaction occurs primarily with ${ }^{17} \mathrm{O}$ in the moderator. The $(\mathrm{n}, \gamma)$ reaction with ${ }^{13} \mathrm{C}$ produces a negligible amount of ${ }^{14} \mathrm{C}$ in SRS reactors. It is more significant in graphite-moderated reactors. The history of actual releases from specific SRS facilities is presented in Chapter 3.

Several small nuclear reactors were used at two SRS locations from the 1950s through the 1970s. The Heavy Water Components Test Reactor, located in B Area, was used in the early 1960 s to test prototype fuels for a proposed heavy-water-moderated power reactor. The other test reactors, located in M Area, were used from the mid-1950s to the late 1970s. The Process Development Pile and the Lattice Test Reactor were used as zero-power mock-up facilities to test components for the production reactors. The Subcritical Experimental Pile also was used to test component designs. The Standard Pile provided neutrons for experiments such as neutron radiography and neutron activation.

Small quantities of ${ }^{14} \mathrm{C}$ were produced at SRS by the test reactors mentioned above and neutron activation analyses. The activity levels of radiocarbon from these sources were insignificant when compared to the activity levels in irradiated nuclear fuel, targets, and moderator. However, these sources are mentioned to provide a complete overview of potential carbon release sources. A more detailed discussion of these miscellaneous sources of activity can be found in earlier reports in this series
(Radiological Assessment Program reports on cesium, strontium, and plutonium).

Certain fuels irradiated at offsite noncommercial facilities were shipped to the SRS for reprocessing. While awaiting reprocessing, the fuels were stored in the Receiving Basin for Offsite Fuel (RBOF), located in $\mathrm{H}$ Area. These fuels contained varying amounts of ${ }^{14} \mathrm{C}$, depending on the fuel type and irradiation history.

Lesser quantities of radiocarbon have been purchased from offsite vendors to use as standards for calibration of analytical instruments, to determine chemical yield in analytical chemical procedures, and as tracers in research studies at the Javannah River Ecology Laboratory.

Table 2-1. Radiocarbon production modes in a nuclear reactor and pertinent nuclear data (Hayes and MacMurdo, 1977)

\begin{tabular}{lcc}
$\begin{array}{c}\text { Neutron- } \\
\text { Induced } \\
\text { Reaction }\end{array}$ & $\begin{array}{c}\text { Natural } \\
\text { Isotopic } \\
\text { Thermal } \\
\text { Neutron } \\
\text { Cross-Section } \\
\text { (barns) }\end{array}$ & $\begin{array}{c}\text { Abundance } \\
\text { of } \\
\text { Target } \\
\text { Element }(\%)\end{array}$ \\
\hline${ }^{14} \mathrm{~N}(\mathrm{n}, \mathrm{p}){ }^{14} \mathrm{C}$ & 1.8 & 99.6 \\
${ }^{17} \mathrm{O}(\mathrm{n}, \boldsymbol{\alpha}){ }^{14} \mathrm{C}$ & 0.24 & 0.039 \\
${ }^{13} \mathrm{C}(\mathrm{n}, \boldsymbol{\gamma})^{14} \mathrm{C}$ & 0.001 & 1.11 \\
\hline${ }^{235} \mathrm{U}(\mathrm{n}, \mathrm{f}){ }^{14} \mathrm{C}$ & $1.7 / 10^{6}$ fissions \\
$($ Temary Fission) & \\
${ }^{239} \mathrm{Pu}(\mathrm{n}, \mathrm{f}){ }^{14} \mathrm{C}$ & $1.8 / 10^{6}$ fissions \\
(Temary Fission) & &
\end{tabular}

SRS reactors may release ${ }^{14} \mathrm{C}$ to the environment by several means. It may be exhausted to the atmosphere as ${ }^{14} \mathrm{CO}$ and ${ }^{14} \mathrm{CO}_{2}$ through the reactor and separation areas ventilation systems, to the aqueous environment by way of liquid waste in waste tanks, or to the Solid Waste Disposal Facility (SWDF), formerly the Burial Ground, on the ion exchange resin (demineralizers) used to maintain moderator purity.

\section{Radiocarbon Produced in the Reactor Moderator}

The predominant mechanism for ${ }^{14} \mathrm{C}$ production in the moderator is the $(n, \alpha)$ reaction with ${ }^{17} \mathrm{O}$. Most of the ${ }^{14} \mathrm{C}$ produced is trapped on demineralizers and buried in the SWDF. Small amounts of ${ }^{14} \mathrm{CO}_{2}$ formed 
in the moderator escape to the blanket gas and are released to the atmosphere via the stack. Small amounts of ${ }^{14} \mathrm{C}(<0.5 \mathrm{Ci} / \mathrm{yr})$ are also formed in the annular cavity outside the reactor tank as the result of neutron capture in the air in the cavity [(by the ${ }^{14} \mathrm{~N}(n, p){ }^{14} \mathrm{C}$ reaction and to a lesser extent the ${ }^{17} \mathrm{O}(\mathrm{n}, \alpha){ }^{14} \mathrm{C}$ reaction)]. This activity is discharged through the exhaust stack. As indicated earlier, nitrogen is present in the moderator as dissolved gas, as the $\mathrm{NO}_{3}{ }^{-}$ion, or as the $\mathrm{NH}_{4}{ }^{+}$ion. ${ }^{14} \mathrm{CO}_{2}$ resulting from the $(n, p)$ reaction with nitrogen behaves identically with that formed from the $(n, \alpha)$ reaction with oxygen.

\section{Radiocarbon in Fuel and Targets Irradiated in Production Reactors}

The ${ }^{14} \mathrm{C}$ formed in fuel and target elements by neutron interactions with oxygen or impurities, and by ternary fission in fissile materials, usually remains bound in the metallic matrix until chemical reprocessing occurs. Loss of ${ }^{14} \mathrm{C}$ by radioactive decay is insignificant because of the long half-life of the isotope (5730 years).

During the chemicall separation process, fuel or target elements are dissolved in nitric acid. Any ${ }^{14} \mathrm{C}$ present is oxidized to ${ }^{14} \mathrm{CO}_{2}$ and passes through the filtration system to the stack. No ${ }^{14} \mathrm{C}$-containing compounds are known to have been sent to the high-level waste tanks from the Purex or HM processes. Wastes from ion-exchange resin regeneration in the RBOF facility may have contributed some ${ }^{14} \mathrm{C}$ to the wastes stored in the waste tanks.

\section{Radiocarbon Purchased Offsite}

As indicated earlier, some radiocarbon has been purchased from offsite vendors for use as analytical standards or radiotracers in research studies. These standards typically are liquids containing less than $10 \mathrm{mCi}$ of activity. Liquid standards are disposed of as low-level waste.

\section{Radiocarbon in Certain Fuels Irradiated Offsite}

Irradiated fuels received from certain offsite facilities were stored underwater in the RBOF until they were ready for chemical separation. The fuels then entered the regular process stream in $\mathrm{H}$ Area. The disposition of carbon is the same as described for fuel irradiated in SRS production reactors.

\section{Radiocarbon in Fuel and Targets Irradiated in Test Reactors}

Fuels and targets from the various test reactors were sent primarily to the RBOF for cooling before chemical separation. Some were sent to the Savannah River Technology Center for research or to reactor material fabrication facilities. Reactor material fabrication facilities only received fuel or targets that were not irradiated and therefore contained no ${ }^{14} \mathrm{C}$. 


\section{Neutron Activation Analysis Samples}

Environmental samples were analyzed by highsensitivity neutron activation for the detection of trace levels of uranium and ${ }^{129} \mathrm{I}$. The neutron flux and irradiation times were not sufficient to produce measurable amounts of ${ }^{14} \mathrm{C}$.

\section{References}

Hayes, D. W., and K. W. MacMurdo, 1977, Carbon-

14 Production by the Nuclear Industry, Health

Physics, 32:215-219. 
This page intentionally left blank. 


\section{Chapter 3. Releases and Stored Inventories of Radiocarbon at the Savannah River Site}

Routine operations at Savannah River Site (SRS) facilities have released radiocarbon to the regional environment surrounding SRS. The largest rcleases occurred from 1959 to 1963 when all five reactors were operating. Slightly smaller releases of radiocarbon originated in the separation facilities, located near the center of the 800-square-kilometer site (Figure 3.I).

is chapter presents data on the calculated and measured releases of radiocarbon from SRS facilities. Additional radiocarbon is buried or stored at the Solid Waste Disposal Facility (SWDF). All measured ${ }^{14} \mathrm{C}$ releases occurred to the atmosphere.

The releases were the result of normal operating events because radiocarbon is formed in normal reactor operations. Mechanisms for formation and release of ${ }^{11} \mathrm{C}$ were discussed in Chapter 2. The formation rates of radiocarbon in the reactor moderator, fuel, targets, and components were calculated from measured concentrations of ${ }^{14} \mathrm{C}$ precursors, measured fluxes, and published neutron-capture cross sections. The calculated values were validated by experimental data (Hayes and MacMurdo, 1977). 


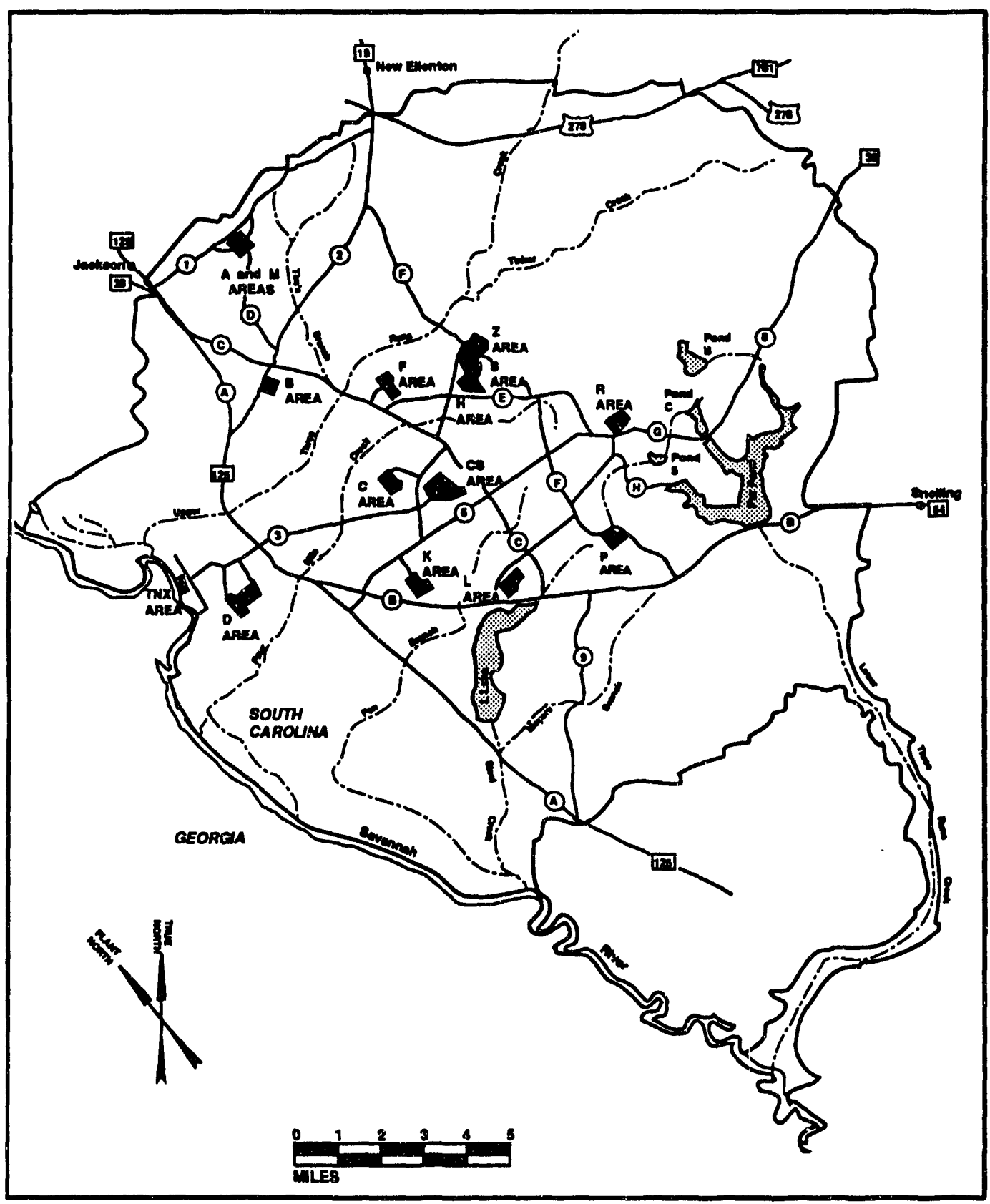

Figure 3.1. The Savannah River Site operating areas 


\section{Reactor Facilities}

The five SRS production reactors are identified by the letter designations $C, K, L, P$, and $R$ (Figure 3.1). The reactors were designed to irradiate various targets to produce special nuclear matcrials (principally, tritium and plutonium) for national defense purposes. Specific radionuclides for other purposes were also produced, including ${ }^{238} \mathrm{Pu}$, a power source for certain deep-space missions.

\section{Facility Operations}

The reactors became operational in 1953-1955 but have not, operated continuously. They have been shut down periodically for maintenance, safety upgrades, os ceplacement of fuel and targets. Prior to 1988 , one reactor was placed on inactive status and another on standby. In 1988, the three remaining reactors were shut down for extensive maintenance and safety upgrades. Current plans call for the operation of only one reactor.

When a nuclear reactor is operating, nuclear-fission reactions occur in the reactor core. The principal components of the core are the fuel, targets, control rods, and moderator. Control rods are neutronabsorbing materials positioned in the core to control the power level of a reactor.

The moderator in SRS reactors is heavy water, which is circulated around the fuel and target elements in the reactor core. The moderator decreases the kinetic energy (slows the speed) of neutrons emitted in the fission process. Slow neutrons have a greater probability for interaction with fuel and target materials than fast neutrons.

The moderator also functions as the primary coolant to remove heat from fuel and target elements. Heat then is transferred from the moderator to the secondary coolant by heat exchangers. SRS reactors used either river or pond water as the secondary coolant in the heat exchangers.

\section{Pathways for Release}

As discussed earlier in Chapter 2, radiocarbon is formed in the moderator by ${ }^{17} \mathrm{O}(\mathrm{n}, \alpha)$ reactions and ${ }^{14} \mathrm{~N}(\mathrm{n}, \mathrm{p})$ reactions. Some ${ }^{\mathrm{s}} \mathrm{the} \mathrm{e}^{14} \mathrm{C}$ formed in the moderator escaped as ${ }^{14} \mathrm{CO}$ and ${ }^{14} \mathrm{CO}_{2}$ to the blanket gas and was vented to the stack. Most of the radiocarbon remained in solution and was removed from the moderator by ion exchange resins in demineralizer units used to maintain moderator purity. Studies indicate that radiocarbon is present on the resin primarily as the bicarbonate ion $\left(\mathrm{HCO}_{3}\right)$.

When a demineralizer unit was exhausted, the ion exchange resin was sent to the SWDF for burial. The normal practice was to displace the $\mathrm{D}_{2} \mathrm{O}$ with $\mathrm{H}_{2} \mathrm{O}$, seal the stainless steel columns with blank flanges, and bury the whole unit. Some $r$ - $\sin$ was removed from the stainless steel shell in the early 1970s and repackaged in concrete casks for burial. Removal and repackaging the resin was discontinued in 1973 and the normal practice of burial in stainless steel shells resumed. Concern about the potential release of ${ }^{14} \mathrm{C}$ to groundwater from buried resin has led to above-ground storage of the sealed demineralizer columns in H Area in more recent years.

The low concentration of ${ }^{14} \mathrm{C}$ in the moderator, coupled with the rinsing of fuel and target tubes to remove entrained moderator, limited the likelihood of transfer of significant quantities of radiocarbon to the Vertical Tube Storage basins. The basin water has not been analyzed for ${ }^{14} \mathrm{C}$, so no estimates are available for releases of this isotope to streams or basins from the reactor areas.

Wastewater was collected in process sumps at the reactor facilities. Occasionally, it contained moderator from leaks that developed during reactor operations or spills that occurred when line breaks were made during maintenance periods. The wastewater was collected and analyzed for radionuclides and moderator content. Possible disposition methods, depending on analysis results, were processing through the Heavy Water Rework Facility or the waste evaporators in the separation areas or discharging to seepage basins or streams. These wastewaters were not analyzed for ${ }^{14} \mathrm{C}$.

\section{Release Monitoring}

Atmospheric releases of radiocarbon have been calculated from known operating power levels and fuel types, using the assumptions given in Hayes and MacMurdo (1977). In more recent years, stack releases of ${ }^{14} \mathrm{C}$ have also been measured to confirm the calculated data. 


\section{History of Releases}

Calculated atmospheric releases of ${ }^{14} \mathrm{C}$ are shown graphically in Figure 3.2 (C Area), Figure 3.3 (K Area), Figure 3.4 (L Area), Figure 3.5 (P Area), and Figure 3.6 ( $R$ Area). The data are presented in tabular form in Table 3-1. The total releases between 1955 and 1988 by area were as follows: $C$, $448 \mathrm{Ci} ; \mathrm{K}, 466 \mathrm{Ci} ; \mathrm{L}, 202 \mathrm{Ci}$;, $475 \mathrm{Ci}$; and R, 137 $\mathrm{Ci}$. The reactor areas together released $1728 \mathrm{Ci}$ of ${ }^{14} \mathrm{C}, 58 \%$ of the total site release. The release data is from Cummins, Hetrick, and Martin, 1991.

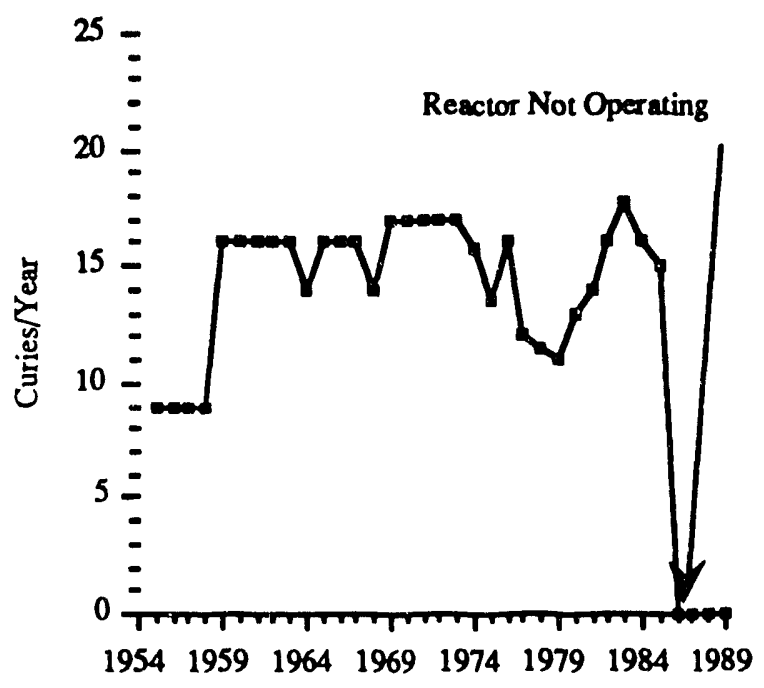

Figure 3.2. Radiocarbon releases to atmosphere, C Area

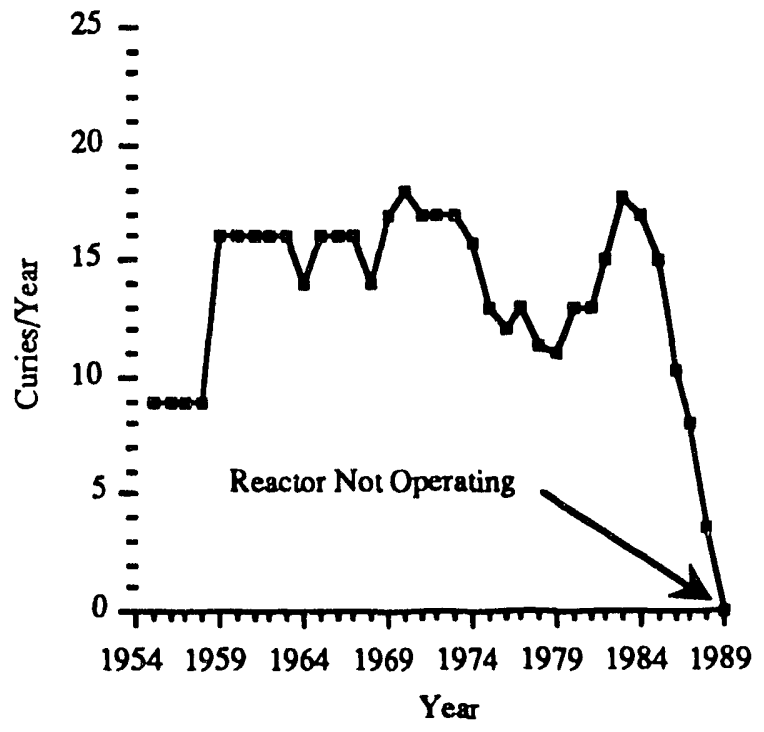

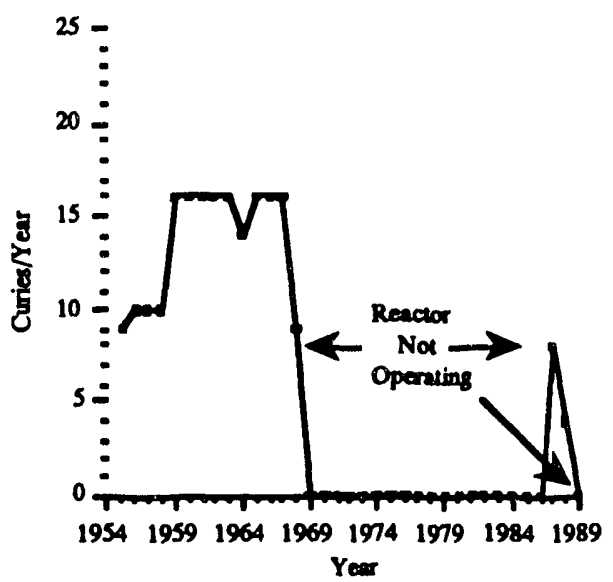

Figure 3.4. Radiocarbon releases to atmosphere, L Area

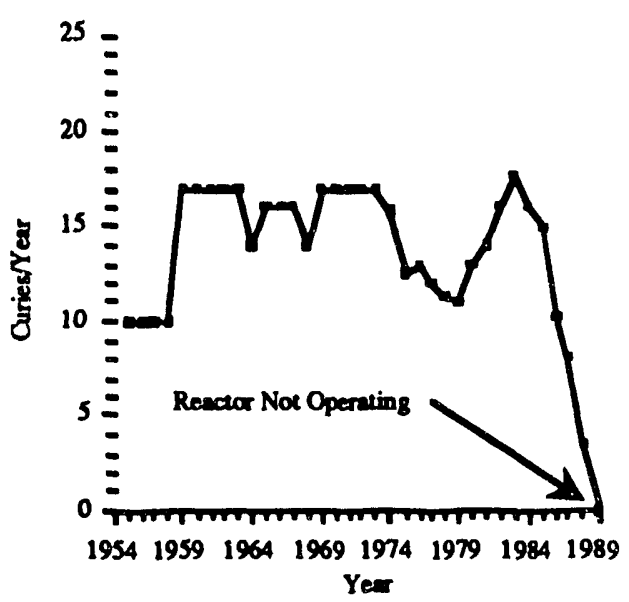

Figure 3.5. Radiocarbon releases to atmosphere, P Area

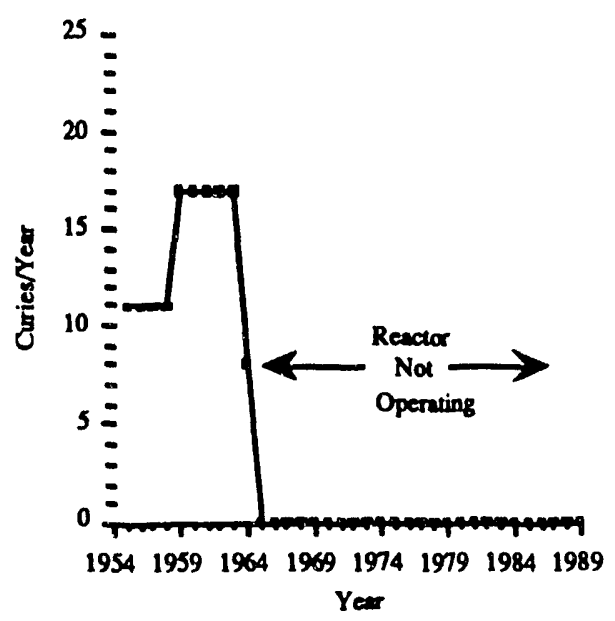

Figure 3.6. Radiocarbon releases to atmosphere, R Area

Figure 3.3. Radiocarbon releases to atmosphere, K Area 
Table 3-1. Aumospheric radiocarbon releases from reactor areas, curies

\begin{tabular}{|c|c|c|c|c|c|}
\hline Year & C Area & K Area & L Area & P Area & $\mathrm{R}$ Area \\
\hline 1955 & 9.00 & 9.00 & 9.00 & 10.00 & 11.00 \\
\hline 1956 & 9.00 & 9.00 & 10.00 & 10.00 & 11.00 \\
\hline 1957 & 9.00 & 9.00 & 10.00 & 10.00 & 11.00 \\
\hline 1958 & 9.00 & 9.00 & 10.00 & 10.00 & 11.00 \\
\hline 1959 & 16.00 & 16.00 & 16.00 & 17.00 & 17.00 \\
\hline 1960 & 16.00 & 16.00 & 16.00 & 17.00 & 17.00 \\
\hline 1961 & 16.00 & 16.00 & 16.00 & 17.00 & 17.00 \\
\hline 1962 & 16.00 & 16.00 & 16.00 & 17.00 & 17.00 \\
\hline 1963 & 16.00 & 16.00 & 16.00 & 17.00 & 17.00 \\
\hline 1964 & 14.00 & 14.00 & 14.00 & 14.00 & 8.00 \\
\hline 1965 & 16.00 & 16.00 & 16.00 & 16.00 & 0.00 \\
\hline 1966 & 16.00 & 16.00 & 16.00 & 16.00 & 0.00 \\
\hline 1967 & 16.00 & 16.00 & 16.00 & 16.00 & 0.00 \\
\hline 1968 & 14.00 & 14.00 & 9.00 & 14.00 & 0.00 \\
\hline 1969 & 17.00 & 17.00 & 0.00 & 17.00 & 0.00 \\
\hline 1970 & 17.00 & 18.00 & 0.00 & 17.00 & 0.00 \\
\hline 1971 & 17.00 & 17.00 & 0.00 & 17.00 & 0.00 \\
\hline 1972 & 17.00 & 17.00 & 0.00 & 17.00 & 0.00 \\
\hline 1973 & 17.00 & 17.00 & 0.00 & 17.00 & 0.00 \\
\hline 1974 & 15.70 & 15.70 & 0.00 & 15.70 & 0.00 \\
\hline 1975 & 13.60 & 12.90 & 0.00 & 12.50 & 0.00 \\
\hline 1976 & 16.00 & 12.00 & 0.00 & 13.00 & 0.00 \\
\hline 1977 & 12.00 & 13.00 & 0.00 & 12.00 & 0.00 \\
\hline 1978 & 11.40 & 11.30 & 0.00 & 11.30 & 0.00 \\
\hline 1979 & 11.00 & 11.00 & 0.00 & 11.00 & 0.00 \\
\hline 1980 & 13.00 & 13.00 & 0.00 & 13.00 & 0.00 \\
\hline 1981 & 14.00 & 13.00 & 0.00 & 14.00 & 0.00 \\
\hline 1982 & 16.00 & 15.00 & 0.00 & 16.00 & 0.00 \\
\hline 1983 & 17.67 & 17.67 & 0.00 & 17.67 & 0.00 \\
\hline 1984 & 16.00 & 17.00 & 0.00 & 16.00 & 0.00 \\
\hline 1985 & 15.00 & 15.00 & 0.00 & 15.00 & 0.00 \\
\hline 1986 & 0.00 & 10.33 & 0.00 & 10.33 & 0.00 \\
\hline 1987 & 0.00 & 8.00 & 8.00 & 8.00 & 0.00 \\
\hline 1988 & 0.00 & 3.52 & 3.96 & 3.52 & 0.00 \\
\hline 1989 & 0.00 & 0.00 & 0.00 & 0.00 & 0.00 \\
\hline$\Sigma$ & 448.37 & 466.42 & 201.96 & 475.02 & 137.00 \\
\hline
\end{tabular}




\section{Separations and Liquid Waste Facilities}

Two chemical separation facilities and their associated liquid-waste storage facilities are located near the center of the site (Figure 3.1). The two separation areas are identified by letter designations $\mathrm{F}$ and $\mathrm{H}$. In these areas, the products of interest from reactor irradiation are chemically separated and purified from waste products.

\section{Facility Operations}

The two chemical separation facilities were used to reprocess irradiated fuel and targets in canyon buildings (221-F and 221-H). Irradiated materials were dissolved and the products of interest chemically separated and purified from waste fission anc activation products. Occasional special campaigns for production of radionuclides such as ${ }^{238} \mathrm{Pu}$ and ${ }^{252} \mathrm{Cf}$ have occurred.

Beginning in late $1954,{ }^{239} \mathrm{Pu},{ }^{237} \mathrm{~Np}$, and ${ }^{238} \mathrm{U}$ generally were recovered from irradiated ${ }^{238} \mathrm{U}$ targets in F Area, which used the Purex chemical extraction process. In $\mathrm{H}$ Area, ${ }^{239} \mathrm{Pu}$ and ${ }^{238} \mathrm{U}$ also were recovered from ${ }^{238} \mathrm{U}$ targets by the Purex process during 1955 to 1959 . The H-Area facility then was modified to recover ${ }^{235} \mathrm{U}$ from irradiated enriched uranium fuel. A further modification in 1963 allowed the recovery of ${ }^{237} \mathrm{~Np}$ from the fuel; the HM process, which stood for $H$ Modified Purex, was used for chemical extraction of the uranium. Also in $\mathrm{H}$ Area, the Frames process was used occasionally to recover ${ }^{238} \mathrm{Pu}$ and ${ }^{237} \mathrm{~Np}$ from special target elements. This process used ion exchange for separation and purification.

Waste facilities in or adjacent to the separation facilities were designed for liquid-waste handling. Carbon salts are relatively insoluble in the highlevel waste, thus the sludge in the waste storage tanks contains most of the inventory of carbon. In November 1988, the Effluent Treatment Facility became operational to treat wastes that previously were sent to seepage basins. The seepage basins were closed in 1988 and have been decommissioned.

\section{Pathways for Release}

Radiocarbon releases from the separation facilities were mainly to the atmosphere. Dissolution of fuel and targets in strong nitric acid solutions assured the oxidation and volatilization of any carbon compounds in the elements being processed. Thus, only small quantities of ${ }^{14} \mathrm{C}$ would exist in any process streams following the dissolution step. Consequently, only low levels of radiocarbon would be expected in seepage-basin streams or in cooling water streams.

Caustic scrubbers were used on the dissolver offgas streams in earlier years to try to minimize the emission of radioiodine. The caustic solution also would trap ${ }^{14} \mathrm{CO}_{2}$. The scrubbers frequently became acidic, however, and the trapped ${ }^{14} \mathrm{CO}_{2}$ readily escaped. Beginning in the early 1960 s, iodine emissions were controlled through longer cooling times, and the caustic scrubber units no longer were used.

\section{Release Monitoring}

Atmospheric releases of ${ }^{14} \mathrm{C}$ from the separation facilities were calculated from known data on fuel and target composition and irradiation histories. Calculated data was confirmed by measurements of stack emissions beginning in 1987.

\section{History of Releases}

Atmospheric releases of ${ }^{14} \mathrm{C}$ are shown graphically in Figure 3.7 (F Area) and Figure 3.8 (H Area) and in tabular form in Table 3-2. The total releases by area were: F Area, $647 \mathrm{Ci}$ and $\mathrm{H}$ Area, $596 \mathrm{Ci}$. The combined total of $1243 \mathrm{Ci}$ released from the separation areas represents $42 \%$ of the site releases for the period 1955-1989.

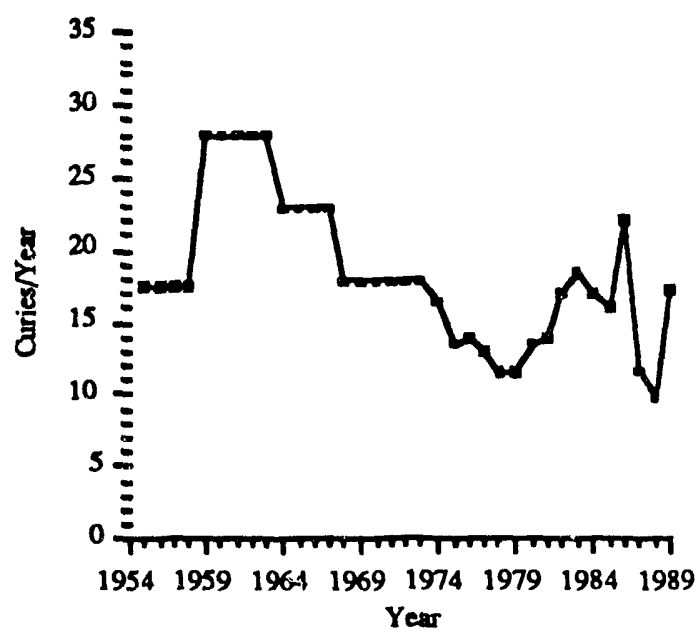

Figure 3.7. Radiocarbon releases to atmosphere, F Area 


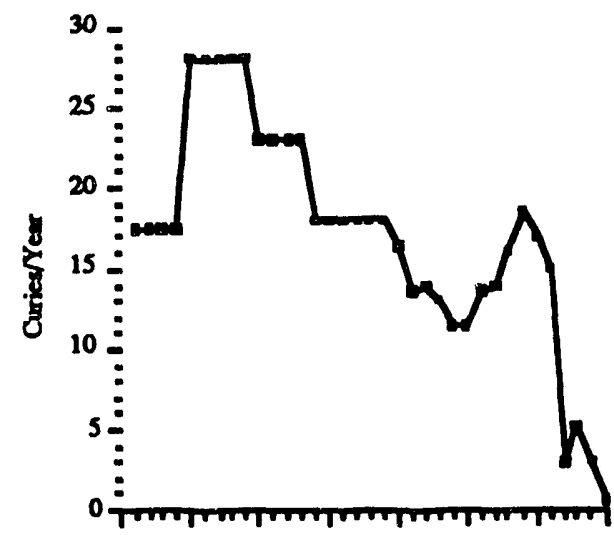

Figure 3.8. Radiocarbon releases to atmosphere, $\mathrm{H}$ Area

\section{References}

Bauman, E. W., 1991, Carbon-14 Removal from Disposal of Reactor Deionizer Resins, WSRC-TR91-566, Westinghouse Savannah River Company, Aiken, SC.

Cook, J. R., 1989, Characterization, Evaluation and Performance Assessment of ${ }^{14} \mathrm{C}$ at the Savannah River Site Low-Level Radioactive Waste Disposal Site, Transactions of the American Nuclear Society, 60, TANSAO 60 1-792, La Grange Park, II.

\section{Solld Waste Disposal Facility}

As indicated in earlier discussions, ion-exchange resins from the moderator purification facility contain significant quantities of ${ }^{14} \mathrm{C}$. Most of the resin is contained inside the stainless steel vessels used to support the resin column during purification operations. A limited amount of resin was removed from the support shell and buried in concrete casks. An estimated total of $6,800 \mathrm{Ci}$ of radiocarbon on ion-exchange resin has been buried at the SWDF (Cook, 1989). An additional 35 spent resin columns are stored above ground in H Area, awaiting the development of techniques to solidify the ${ }^{14} \mathrm{C}$ in a more compact and less leachable form (Bauman, 1991).

Cummins, C. L., C. S. Hetrick, and D. K. Martin, 1991, Radioactive Releases at the Savannah River Site 1954-1989, WSRC-RP-91-684, Westinghouse Savannah River Company, Aiken, SC.

Hayes, D. W. and K. W. MacMurdo, 1977. Carbon-14 Production by the Nuclear Industry, Health Physics, 32:215-219. 
Table 3-2. Atmospheric radiocarton releases from Separations areas, curies

\begin{tabular}{ccc} 
Year & F Area & H Area \\
\hline 1955 & 17.50 & 17.50 \\
1956 & 17.50 & 17.50 \\
1957 & 17.50 & 17.50 \\
1958 & 17.50 & 17.50 \\
1959 & 28.00 & 28.00 \\
1960 & 28.00 & 28.00 \\
1961 & 28.00 & 28.00 \\
1962 & 28.00 & 28.00 \\
1963 & 28.00 & 28.00 \\
1964 & 23.00 & 23.00 \\
1965 & 23.00 & 23.00 \\
1966 & 23.00 & 23.00 \\
1967 & 23.00 & 23.00 \\
1968 & 18.00 & 18.00 \\
1969 & 18.00 & 18.00 \\
1990 & 18.00 & 18.00 \\
1971 & 18.00 & 18.00 \\
1972 & 18.00 & 18.00 \\
1973 & 18.00 & 18.00 \\
1974 & 16.50 & 16.50 \\
1975 & 13.50 & 13.50 \\
1976 & 14.00 & 14.00 \\
1977 & 13.00 & 13.00 \\
1978 & 11.50 & 11.50 \\
1979 & 11.50 & 11.50 \\
1980 & 13.50 & 13.50 \\
1981 & 14.00 & 14.00 \\
1982 & 17.00 & 16.00 \\
1983 & 18.50 & 18.50 \\
1984 & 17.00 & 17.00 \\
1985 & 16.00 & 15.00 \\
1986 & 22.00 & 3.00 \\
1987 & 11.60 & 5.40 \\
1988 & 9.75 & 3.25 \\
1989 & 17.21 & 0.69 \\
& & \\
$\Sigma$ & 646.62 & 596.34 \\
& &
\end{tabular}




\section{Chapter 4. Radiosarbon Concentrations and Transport Mechanisms}

Although ${ }^{14} \mathrm{C}$ is released to the atmosphere from SRS operations, it is =ot monitored in the environment because background levels from nuclear device testing and the interaction of cosmic rays in the upper atmosphere greatly exceed the SRS contribution. 
This page intentionally left blank. 


\section{Atmospheric Concentration and Transport}

One of the larger contributors to pub'ic radiation dose from atmospheric releases is : $\mathrm{C}$, yet no routine measurements are made of the concentration of ${ }^{14} \mathrm{C}$ in air. To understand why this is the case, the expected levels of ${ }^{14} \mathrm{C}$ must be compared with the background concentration.

The ${ }^{14} \mathrm{C}$ background is primarily from two sources: the fallout from nuclear device tests and the natural production of ${ }^{14} \mathrm{C}$ in the upper atmosphere. Production of ${ }^{14} \mathrm{C}$ by the nuclear industry is several orders of magnitude less than either of these sources (NCRP, 1985). Natural ${ }^{14} \mathrm{C}$ production results in an isotopic abundance of $6 \mathrm{pCi} / \mathrm{g}$ of carbon (UNSCEAR, 1982). Using an average carbon dioxide concentration of $340 \mathrm{ppm}$ results in an atmosnheric concentration of $1.0 \mathrm{pCi} / \mathrm{m}^{3}$.

The ${ }^{14} \mathrm{C}$ concentration from nuclear testing peaked in 1963 at an isotopic abundance equal to that of natural ${ }^{14} \mathrm{C}$. By 1970, this had decreased to about $3 \mathrm{pCi} / \mathrm{g}$ of carbon. Extrapolation suggests that the abundance from nuclear testing should be about $1 \mathrm{pCi} / \mathrm{g}$ of carbon by 1992 (NCRP, 1985). The contribution from nuclear testing to the background air concentration is about $0.2 \mathrm{pCi} / \mathrm{m}^{3}$. The amount of ${ }^{14} \mathrm{C}$ in the atmosphere is decreasing largely because of absorption and sequestering of carbon dioxide in the ocean. Almost all of the ${ }^{14} \mathrm{C}$ in the lower atmosphere and in SRS releases is in the chemical form of carbon dioxide.

The contribution of SRS release to the air concentration in the vicinity of SRS can be estimated from the measured atmospheric tritiated water concentration. The ${ }^{14} \mathrm{C}$ concentration should be equal to the measured tritiated water concentration multiplied by the ratio of the ${ }^{14} \mathrm{C}$ to tritiated water release. This calculation was performed for the average concentrations and the total releases for the period 1985 through 1988. During this period, $1,330,000 \mathrm{Ci}$ of tritiated water and $187 \mathrm{Ci}$ of ${ }^{14} \mathrm{C}$ were released to the armosphere. The results, shown in Table 4-1, are averaged by distance from the center of SRS. The averages at given radial distances characterize the distribution of air concentrations in the SRS vicinity because the distribution of wind velocity at the site is approximately uniform, leading to circular isopleths if concentration. As the results indicate, for all the of ísite sampling locations, the percent of ${ }^{14} \mathrm{C}$ dus to SRS releases is too small to be detected against background.

Using the atmospheric concentrations from Table 4-1 and an estimate of the net carbon uptake by the ecosystem at SRS, it is possible to make an estimate of the ${ }^{14} \mathrm{C}$ deposited within the site boundary or within any circular area centered around the site. Net carbon uptake from the atmosphere has been measured for many ecosystems. SRS is characterized by forest ecosystems. Approximately $60 \%$ of the land area is in pine stands. The remaining land is either bottom land or upland deciduous forest, of which about $20 \%$ is classified as wetlands. The remainder is water surface, fields, or cleared land around facilitics. The net carbon uptake of forest systems varies from less than zero in mature stands that are in growth decline to greater than $5000 \mathrm{~g} / \mathrm{m}^{2}$ in rapidly growing young stands that are accumulating mass (IBP, 1981).

Table 4-1. Estimation of the atmospheric concentration of radiocarbon in the vicinity of the Savannah River Sitc relative to background radiocarbon

\begin{tabular}{lcccc}
\multicolumn{1}{c}{ Location } & $\begin{array}{c}\text { Average } \\
\text { Distance }(\mathbf{k m})\end{array}$ & $\begin{array}{c}\text { HTO } \\
\text { Concentration } \\
\left(\mathbf{p C i}^{3} \mathbf{m}^{3}\right)\end{array}$ & $\begin{array}{c}{ }^{14} \mathrm{C} \\
\text { Concentration } \\
\left(\mathbf{p C i} / \mathbf{m}^{3}\right)\end{array}$ & $\begin{array}{c}\text { Percent of } \\
\text { Background }\end{array}$ \\
\hline Onsite & & & & \\
SRS Perimeter & 3.0 & 1243 & 0.174 & 14.8 \\
25 Miles $(40 \mathrm{~km})$ & 15.9 & 84.1 & 0.012 & 0.91 \\
100 Miles $(155 \mathrm{~km})$ & 39.5 & 23.8 & 0.003 & 0.28 \\
& 155.3 & 10.7 & 0.002 & 0.13
\end{tabular}


Based on research at SRS and comparable studies at other locations in the Southeast, a $700-1000 \mathrm{~g} / \mathrm{m}^{2}$ range appears reasonable (Ralston, 1974, and Murphy, 1985). Integrating the air ${ }^{14} \mathrm{C}$ concentration and the net uptake of carbon leads to an estimate that between $0.15 \%$ and $0.3 \%$ of the released ${ }^{14} \mathrm{C}$ is taken into the ecosystems at the SRS each year. Similarly, Between $0.4 \%$ and $0.8 \%$ of the ${ }^{14} \mathrm{C}$ will be taken up within an $80-\mathrm{km}$ circle around SRS. This is about $2 \%$ of the uptake of background ${ }^{14} \mathrm{C}$.
It should be emphasized that the uptake results frem the addition of carbon to the ecosystem. The isotopic abundance of ${ }^{14} \mathrm{C}$ in the biomass accumulated by the ecosystem would be expected to be only slightly less than the abundance in the atmosphere at the time the biomass was produced. Given enough time, the SRS ecosystem would come into equilibrium with the atmospheric ${ }^{14} \mathrm{C}$ concentration, and no net uptake would occur.

\section{Surface Water Transport}

As indicated previously, there are no known releases of ${ }^{14} \mathrm{C}$ to surface water at SRS. A description of the surface waters may be found elsewhere (Cariton et al., 1992).

\section{Groundwater Concentrations and Transport}

\section{The Savannah River Site Groundwater System}

SRS lies on the Atlantic Coastal Plain, about 20 miles southeast of the edge of the Piedmont Physiographic Province. The Coastal Plain is underlain by a seaward-dipping wedge of sediments that thins to the northwest where it contacts the exposed crystalline rocks of the Piedmont. Early investigations of the site hydrogeology (Siple, 1967) established three geologic and hydrogeologic systems as follows:

- crystalline basement rocks composed of metamorphic and intrusive igneous rocks

- well-indurated Triassic-aged sediments in the Dunbarton Basin

- the overlapping, weakly consolidated Cretaceous to Recent Coastal Plain sediments

The crystalline basement rocks have very low permeabilities. Water is stored primarily in the fractures and joints in the rocks. The permeability of the Triassic rocks also is likely to be relatively low. Two test wells drilled into the Triassic rocks showed that the water in these rocks is geopressured and that the hydraulic head of the water is above land surface. The origin of the overpressuring is uncertain but has been ascribed to osmotic pressure across the overlying impermeable confining units (Marine, 1974).

Both the crystalline basement and Triassic rocks are overlain by varying thicknesses of weathering residue containing degraded minerals and clay. Overlying these old soils is a depositional blanket of indurated, poorly sorted clayey sediments of the Cape Fear Formation (Bledsoe, 1988). This unit isolates the younger, sedimentary materials from the Triassic sediments and crystalline basement rocks.

The third hydrogeologic system consists of the Cretaceor's and younger Coastal Plain sediments. The sediments were largely deposited in shallow marine and fluvial environments (Gohn, 1988). The thickness of the sedimentary units increases toward the southeast across the site, ranging from about 700 feet at the northwest boundary to about 1400 feet at the southeastern boundary. The stratigraphic names applied to the various units have been modified as more detailed information has become available. The principal aquifers frequently have been named after the principal formations; for example, the Barnwell Formation and the Barnwell Aquifer. As stratigraphic names have changed, the names of the aquifers have been changed.

Figure 4.1 compares some of the changes that have occurred in the hydrostratigraphic nomenclature since the mid-1960s. The currently recommended nomenclature (Aadland et al., 1992) takes into account the progressive thickening of the aquifers across the site and the effectiveness of the confining units that separate the aquifer units. The recent changes avoid tying the aquifer nomenclature to the lithostratigraphic names and extend existing hydrostratographic nomenclature from surrounding regions into SRS. 

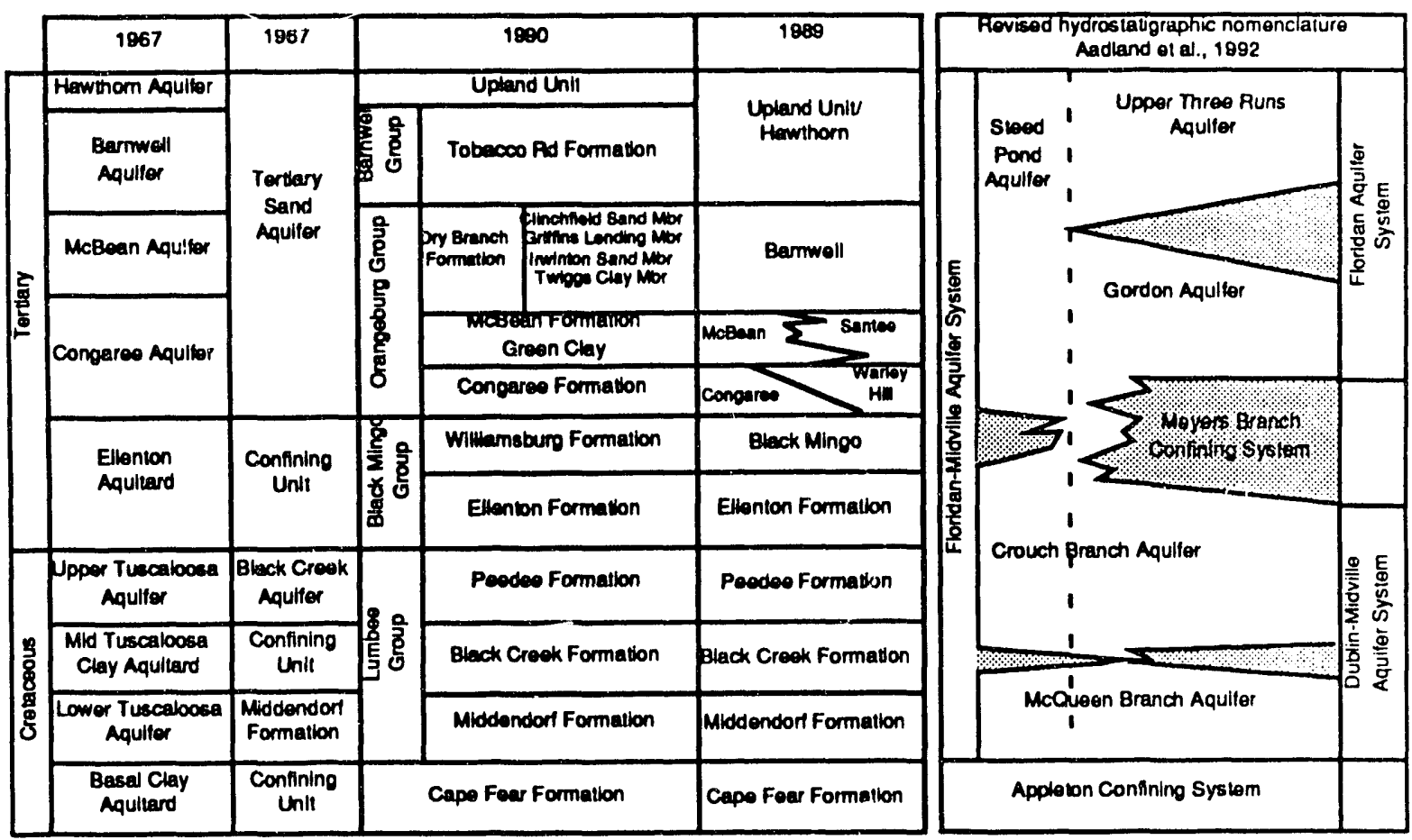

Figure 4.1. Stratigraphic and hydrostratigraphic nomenclature used on the Savannah River Site

At the base of the Coastal Plain sediments is an aquitard, the Appleton Confining System, composed of residual soils of the basement rocks and dense clays of the Cape Fear Formation. Overlying this contining unit are two aquifers in Cretaceous sands, McQueen Branch and Crouch Branch. The sands generally are considered to be prolific water producers and generally are the source of water for water supply wells on the site. They are separated from each other by the relatively less permeable beds that make up the Black Creek Formation.

The Tertiary aquifers are separated from the underlying Cretaceous aquifer units by confining beds of the Black Mingo Group, especially the Ellenton Formation. On the northwestern comer of site, the separation is not as effective as in the southern portion.

In the southeastern area, the Tertiary section can be divided into two separate aquifers, the Gordon (formerly called the "Congaree Aquifer") and Upper Three Runs (frequently referred to as the "Bamwell Aquifer" or "Watertable Aquifer"). The aquitard or confining bed that separates these two units is a glauconitic clayey zone of the McBean Formation locally referred to as the "green clay." This clay pinches out and becomes more sandy toward the northwest.
In some areas of the site, it is necessary to modify the hydrostratigraphic nomenclature because of local changes in lithologies and topography. For example, in some portions of the site, an aquitard unit referred to as "tan clay" subdivides the uppermost aquifer into two separate zones. In the southern portion of the site, the "tan clay" unit is thin or sporadic and does not form a consistent aquitard.

The level of the water table is controlled primarily by local topographic features. The surface of the Atlantic Coastal Plain at the site is a relatively flat plateau (the Aiken Plateau) dissected by stream erosion. The incision of the streams has left relatively isolated, flat-lying surfaces separated by stream valleys $90 \mathrm{fect}$ to 125-feet deep. The depth to the water table below land surface varies from 0 feet, when it outcrops in the stream valleys or wetlands, to $125 \mathrm{fect}$ below the remnant-plateau areas. The depth of the water table usually is controlled by the elevation of the nearest Savannah River tributary stream. At many localitics on site, the water table is situated in tertiary sediments of low water-producing capabilities, and perched water tables exist sporadically across the site

The direction of groundwater flow at any locality may change or even reverse in successively deeper aquifers. The aquifers in the tertiary sediments receive local recharge, and flow generally is toward 
nearby stream valleys. In general, flow at the water table is toward minor tributaries, while deeper tertiary aquifers flow toward major tributaries of the Savannah River. The deepest aquifers at SRS, the Dublin-Midville aquifer system, receive recharge in the outcrop areas of the Cretaceous sediments north of the site. Groundwater flow beneath the site in this system is toward the Savannah River.

Over much of the site, the potentiometric surface, or hydraulic "head" of the deeper aquifers in the cretaceous sediments is higher than that of the overlying tertiary aquifers (Christensen and Gordon, 1983). This head reversal is an important characteristic of many of the waste disposal areas and has provided protection to the deeper aquifers on the site from downward transport of contaminants. Figure 4.2 outlines the areas where there is an upward hydraulic gradient across the confining units near the Cretaceous-Tertiary boundary.

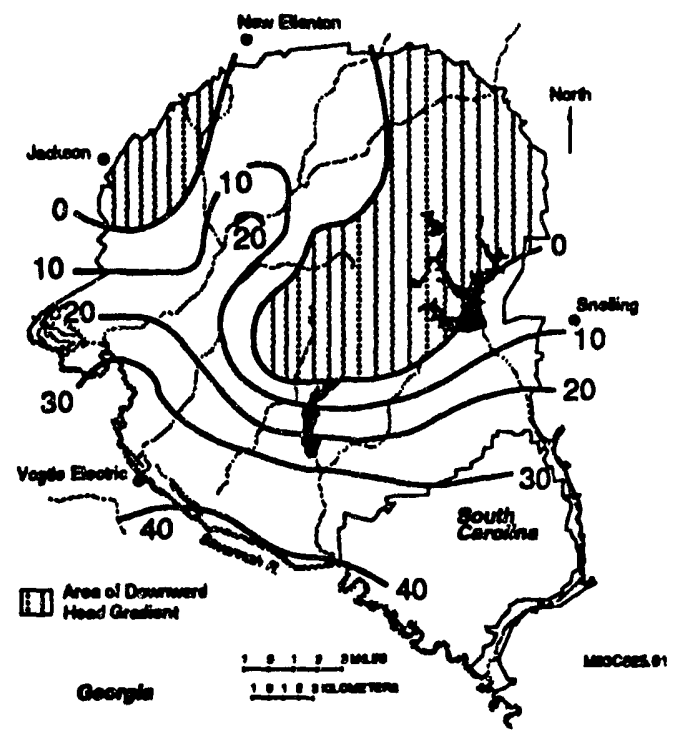

Figure 4.2. Hydraulic head differences across confining units near the cretaceoustertiary boundary

\section{Radiocarbon in the Savannah River Site Groundwater}

\section{General}

SRS groundwater monitoring is performed by the Environmental Monitoring Section of the Environmental Protection Department using a system of wells that has been installed around each facility, and especially around each of the waste disposal areas and seepage basins. The majority of these wells are sampled quarterly, and the results reported in the annual Savannah River Site Environmental Report.

The environmental geochemistry of inorganic carbon is well understood. The chemical system $\mathrm{CO}_{2}-\mathrm{H}_{2} \mathrm{O}$ has been studied extensively. It is the classical textbook system used to teach the principles of aqueous chemistry (Garrels and Christ, 1965; Drever, 1988; Domenico and Schwartz, 1990). These texts provide a thorough coverage of how this system behaves. Carbon dioxide $\left(\mathrm{CO}_{2}\right)$ will dissolve in water up to a limit proportional to the partial pressure of $\mathrm{CO}_{2}$ in the atmosphere. Part of the dissolved $\mathrm{CO}_{2}$ reacts with water to form carbonic acid $\left(\mathrm{H}_{2} \mathrm{CO}_{3}\right)$. The carbonic acid can undergo further reactions by breaking into a bicarbonate ion $\left(\mathrm{HCO}_{3}{ }^{-}\right)$and proton $\left(\mathrm{H}^{+}\right)$. The bicarbonate ion can break up in similar fashion, forming a carbonate ion $\left(\mathrm{CO}_{3}{ }^{-2}\right)$. Thus, the dissolution of carbon dioxide results in lower $\mathrm{pH}$ through the dissociation of carbonic acid. The dominant form of the carbonic acid is controlled by the $\mathrm{pH}$ of the water. In the common range of $\mathrm{pH}$ found in natural waters $\mathrm{pH} 5$ to 9), carbonic acid and bicarbonate are the dominant forms (Drever, 1988). All of the above forms of carbon collectively are known as inorganic carbon.

The carbon dioxide content of soil gas generally is higher than that of the atmosphere (Domenico and Schwartz, 1990). Thus, the carbon dioxide content of infiltrating rainwater will tend to increase as the water seeps through the soil. The ${ }^{14} \mathrm{C}$ in the inorganic carbon will tend to remain in solution. The increase in dissolved $\mathrm{CO}_{2}$ will lower the $\mathrm{pH}$ further, enhancing the solubility of carbonate rocks. Hence, the soil solution will dissolve carbonate sediments through which it flows.

The dominant forms of ${ }^{14} \mathrm{C}$ transport in groundwater are dissolved $\mathrm{CO}_{2}$, carbonic acid, and bicarbonate ion due to the natural range of $\mathrm{pH}$ found in most groundwaters. The transport may be slowed by adsorption of these components on grain surfaces. This process generally is described by assuming an equilibrium partitioning of the inorganic carbon between the solids and the solution passing through them. This equilibrium is modeled with the distribution coefficient $K_{d}$, which is the ratio of the amount of inorganic carbon on the sediments to the 
amount dissolved in the solution. The higher the $K_{d}$ (the more carbon bound to the sediments), the slower will be the rate of transport through the subsurface. McIntyre, 1988, determined that for SRS soils the $K_{d}$ for ${ }^{14} \mathrm{C}$ is approximately $55 \mathrm{~mL} / \mathrm{g}$, which is relatively low. Thus, the carbon is not strongly tied up on the sediments, but is relatively free to move with the groundwater.

The primary pathway, although low level, for ${ }^{14} \mathrm{C}$ entering the groundwater on the site has been through discharges to seepage basins in the General Separation Areas. Leaching of wastes in the SWDF is another potential source of ${ }^{14} \mathrm{C}$. No analyses for ${ }^{14} \mathrm{C}$ are available from reactor area seepage or retention basins, nor from the high-level waste tanks.

\section{General Separation Area Basins}

During the period 1954 to 1988 , seepage basins were used at SRS for the disposal of wastewater that contained low concentrations of chemicals and radionuclides. The seepage basins were intended to delay the release of radionuclides that could not otherwise be contained and to allow time for radioactive decay to decrease the activity (Reichert, 1968). Several of these basins were located in the General Separation Areas near F Area and H Area (see Figure 4.3).

\section{F-Area Seepage Basins}

The first seepage basin onsite was constructed in 1954, just north of F Area, but the seepage rate was too low to handle the volume of wastewater coming from the F-Area facilities. Three additional basins were constructed south of $F$ Area and received effluent during the period 1954 to 1988 . Water infiltrating from the F-Area seepage basins encounters a perched water table 15 to 25 fect below the surface and then a normal water table 60 to 65 feet below the land surface. Flow of water at the water table aquifer is toward Four Mile Creek at a rate estimated to be about $0.5 \mathrm{ft} / \mathrm{d}$ (Stone and Christensen, 1983). The water infiltrating from these basins produces a plume that can be identified in monitor wells by its high conductivity and tritium activities.

Stone and Christensen, 1983, reviewed the thenavailable groundwater data and found only tritium, ${ }^{90} \mathrm{Sr}$, and uranium to be notably mobile in the subsurface at this site. Analyses for ${ }^{14} \mathrm{C}$, however, were not done at that time. Quarterly sampling for this sonstituent was begun in the summer of 1989 .

Sixteen wells registered levels of ${ }^{14} \mathrm{C}$ at least once during the short sampling period of record. Data from 12 of these wells which had more than one positive result, is contained in Table 4-2. The locations of the wells are shown in Figure 4.4. The range of concentration was from $<10$ to $270 \mathrm{pCi} / \mathrm{L}$. For reference, the EPA drinking water standard for ${ }^{14} \mathrm{C}$ is $2000 \mathrm{pCi} / \mathrm{L}$. Of those $1 \overline{\mathrm{w}}$ wells, 10 showed a trend of increasing ${ }^{14} \mathrm{C}$; two showed a mixed trend, first decreasing and then increasing; and one showed a very questionable downward trend. It is important to note that the sampling record does not begin until a year after use of the seepage basins was discontinued in 1988. The trends might be due to seasonal rainfall patterns or short-term loading patterns in the waste streams to the basins. Therefore, they do not necessarily indicate any long-term trends.

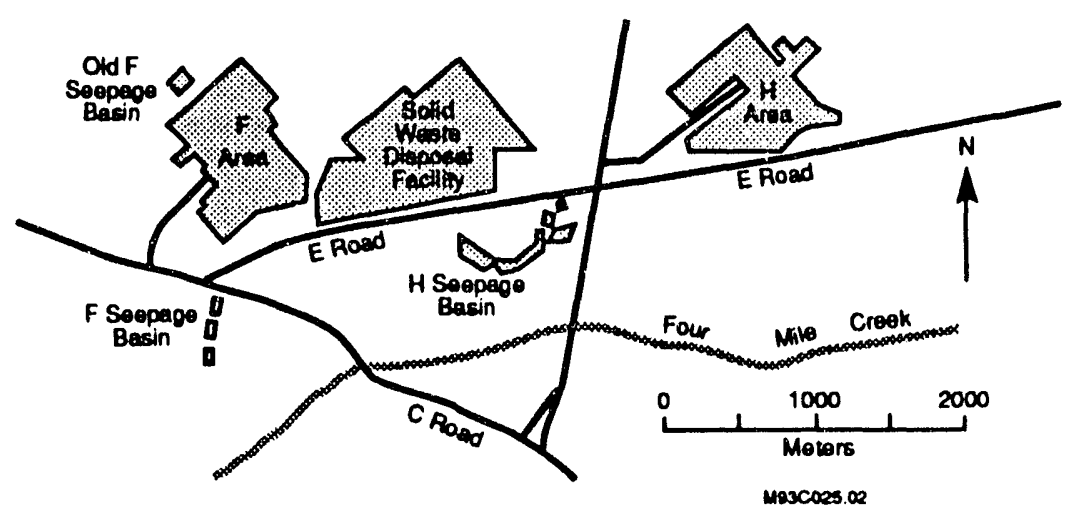

Figure 4.3. Location map of General Separations Area 
Table 4-2. Ranges and average concentrations of radiocarbon in F-Area wells with radiocarbon levels above the detection limit

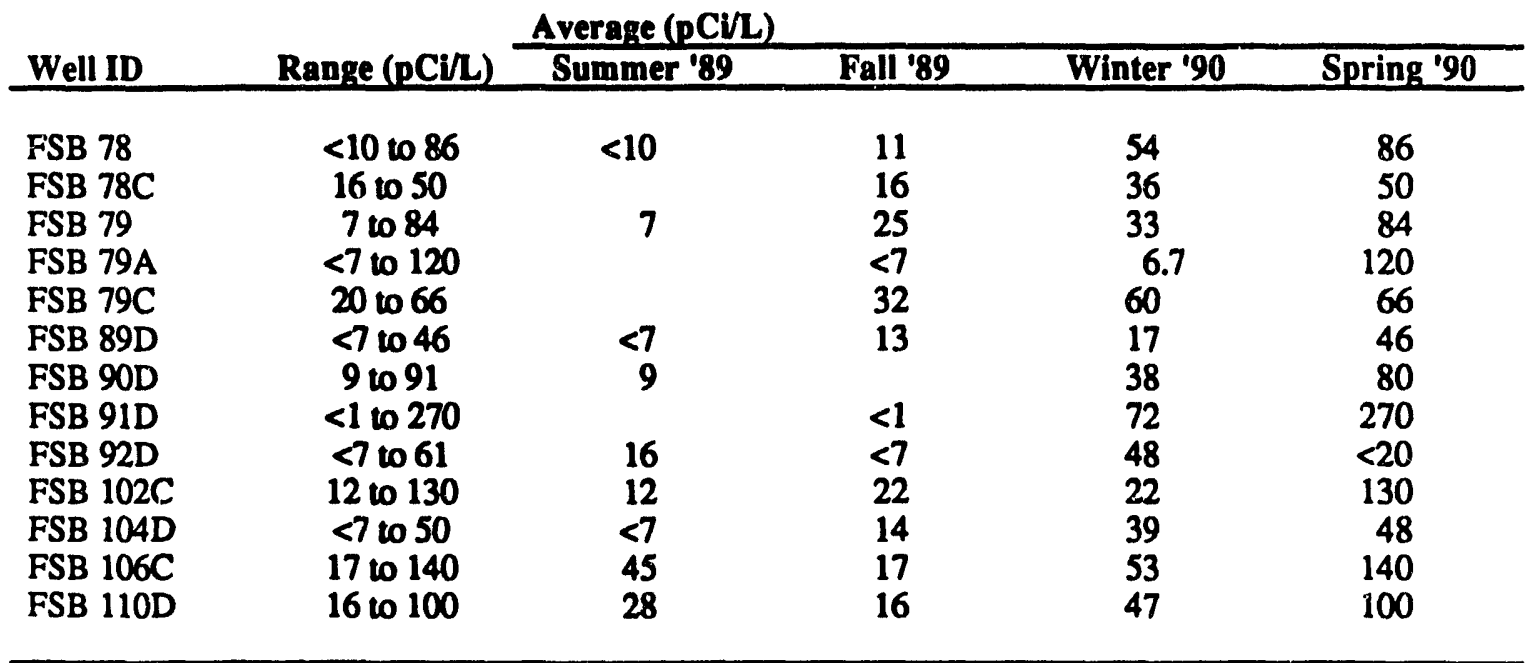

\section{H-Area Seepage Basins}

The four H-Area seepage basins covered an area of $42,700 \mathrm{~m}^{2}$ and were used from 1955 to 1988 . The majority of the liquids discharged to these basins contained low-level radioactivity from the $\mathrm{H}$ Area separation facility. The effluents to these basins contained metals, including mercury and cadmium, nitrate in the form of $\mathrm{HNO}_{3}$, and $\mathrm{NaOH}$ (Killin et al., 1935). The basins were closed in 1988 and have since been capped.

Though in close proximity to the F-Area basins, the hydrogeology at the H-Area basins differs. The depth of the water table is only about 20 feet, and the basins are located closer to the groundwater-discharge zone along Four Mile Creek. Much of the groundwater flow in this area appears to occur in narrow, highly permeable channels in the sedimen.is. While a small percentage of the seepage-basin waters penetrate into a deeper aquifer, the majority migrate to an outcrop of the water table, or "seepline," above Four Mile Creek (Figure 4.5).
Groundwater monitoring for radioactive constituents in $\mathrm{H}$ Area has been conducted since the basins began operations. As in F Area, about half of the nonvolatile beta in the groundwater is ${ }^{90} \mathrm{Sr}$. Other nonvolatile beta emitters in the groundwater include ${ }^{63} \mathrm{Ni},{ }^{89} \mathrm{Sr}$, ${ }^{99} \mathrm{Tc},{ }^{129} \mathrm{I},{ }^{134} \mathrm{Cs}$, and ${ }^{137} \mathrm{Cs}$. Specific measurements for ${ }^{14} \mathrm{C}$ were begun in 1989 . Table 4-3 contains data from wells that had ${ }^{14} \mathrm{C}$ levels notably above the detection limit. Well locations are shown in Figure 4.5. Most of the wells have nondetectable or only moderate concentrations of ${ }^{14} \mathrm{C}$. There are a few notable exceptions. Wells HSB 103D, 105D, 107D, $114 \mathrm{D}$, and 129D have had ${ }^{14} \mathrm{C}$ concentrations of a few hundreds of $\mathrm{pCi} / \mathrm{L}$. Well HSB 101D has had several high concentrations. The fall 1989 and winter 1990 results were 430 and $580 \mathrm{pCi} / \mathrm{L}$, and the spring 1990 result was $1500 \mathrm{pCi} / \mathrm{L}$. This result approaches the drinking water standard of $2000 \mathrm{pCi} / \mathrm{L}$. The pattern of ${ }^{14} \mathrm{C}$ measured in the wells suggests that moderately low levels (on the order of tens of $\mathrm{pCi} / \mathrm{L}$ ) probably are discharging to Four Mile Creek. 


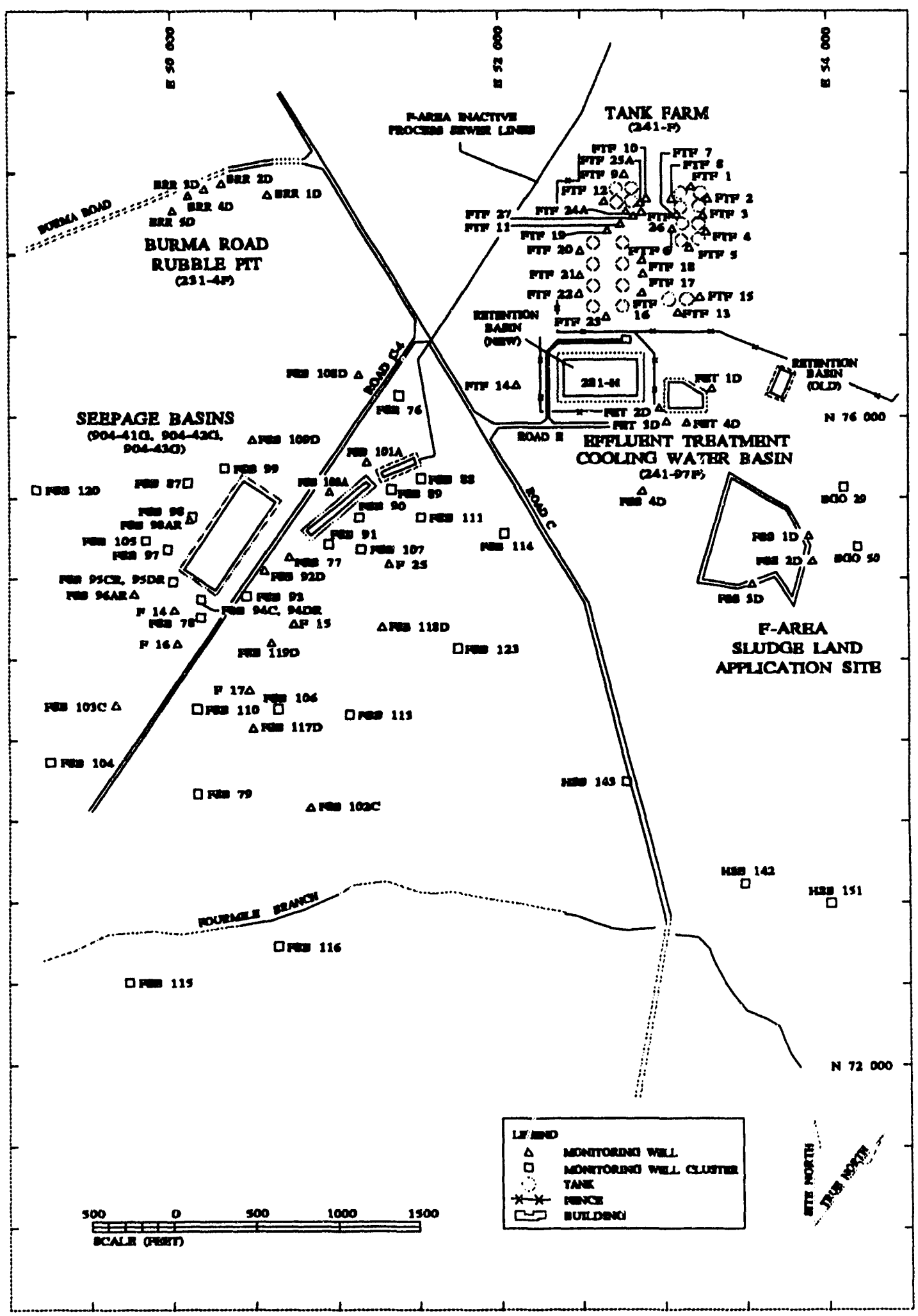

Figure 4.4. Groundwater monitoring near F-Area seepage basins 
Table 4-3. Ranges and average concentrations of radioacarbon in H-Area wells with radiocarbon levels above the detection limit

\begin{tabular}{|c|c|c|c|c|c|}
\hline \multirow[b]{2}{*}{ Well ID } & \multirow[b]{2}{*}{ Range (pCVL) } & \multicolumn{4}{|c|}{ Average (pCi/L) } \\
\hline & & Summer '89 & Fall 89 & Winter' 90 & Spring '90 \\
\hline HSB 69 & $18 t 0160$ & 48 & 18 & 90 & 145 \\
\hline HSB 86C & 2910200 & & 29 & 60 & 200 \\
\hline HSB 86D & 14 to 110 & & 14 & 35 & 94 \\
\hline HSB 101D & 27 to 1500 & 27 & 430 & 580 & 1500 \\
\hline HSB 103D & $<9$ to 150 & $<9$ & 24 & 43 & 150 \\
\hline HSB 105D & $<7$ to 210 & $<7$ & 70 & 38 & 210 \\
\hline HSB 107D & $<10$ to 160 & $<10$ & 21 & 68 & 130 \\
\hline HSB 114D & $<9$ to 120 & $<9$ & & 32 & 120 \\
\hline HSB 116D & $<10$ to 33 & $<10$ & 19 & 31 & 33 \\
\hline HSB 129D & 2610180 & & 39 & 81 & 140 \\
\hline HSB 134D & 13 to 72 & 13 & 16 & 40 & 72 \\
\hline HSB 137D & 17 to 48 & 21 & 17 & 23 & 48 \\
\hline
\end{tabular}

\section{Solid Waste Disposal Facllity}

As noted in a previous section, some of the moderator ion-exchange resin was removed from its stainless steel jacket and placed in concrete containers before burial in the early 1970 s. Leaching of this material could contribute ${ }^{14} \mathrm{C}$ to the groundwater. Most monitoring well results to date have shown nondetectable to quite low levels. Well BGO 8A had one measurement of $81 \mathrm{pCi} / \mathrm{L}$. The next highest levels observed were $37 \mathrm{pCi} / \mathrm{L}$ in well BGO 7D and $22 \mathrm{pCi} / \mathrm{L}$ in well BGO 37C. The remaining results were all less than $20 \mathrm{pCi} / \mathrm{L}$. The locations of these wells are shown in Figure 4.5.

\section{Summary}

${ }^{14} \mathrm{C}$ is relatively mobile in SRS groundwater. Little data is available to assess the full extent of this nuclide in the site's groundwater. It is potentially a contributor to radioactivity in the SRS groundwater environment. 


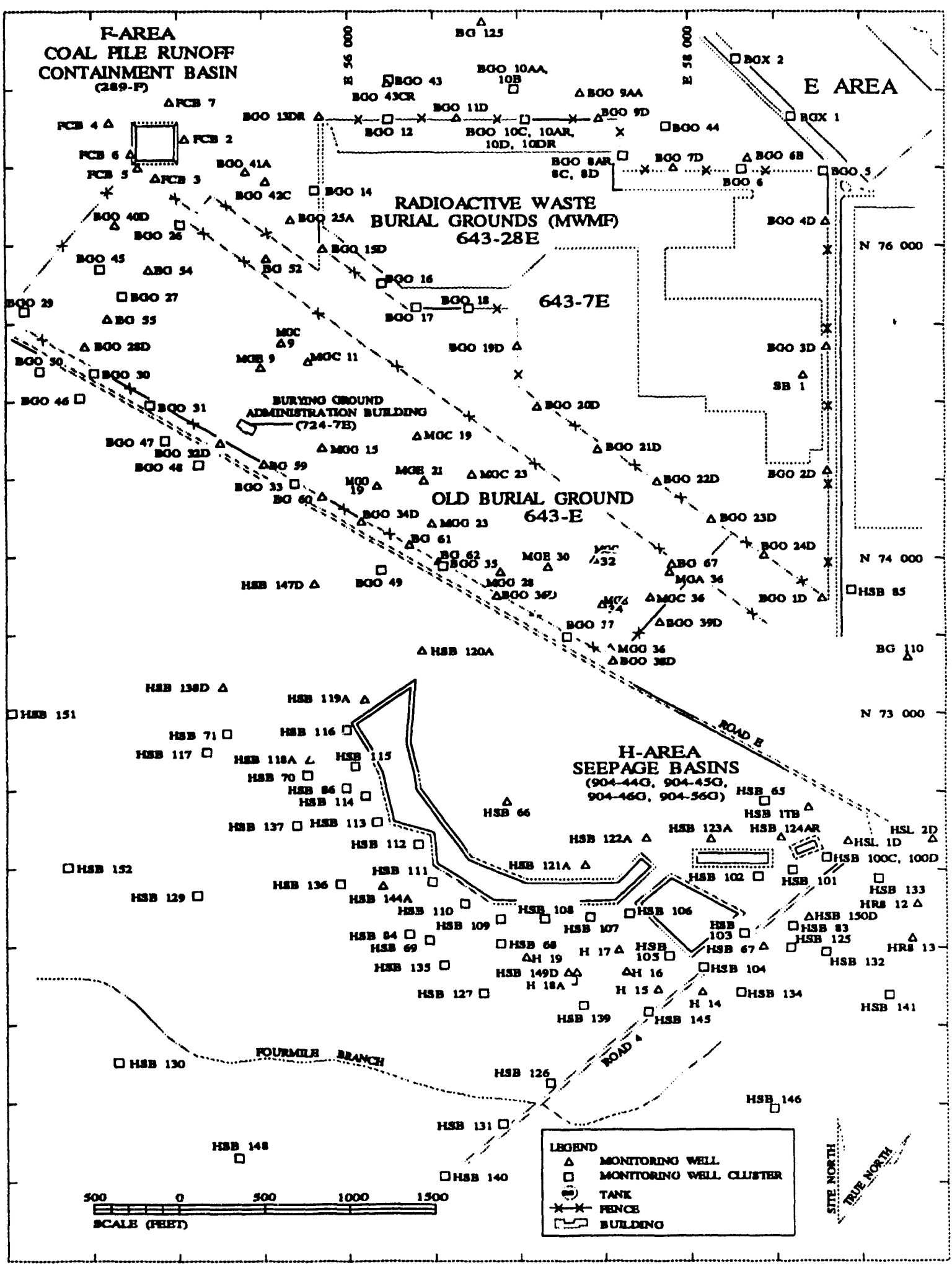

Figure 4.5. Groundwater monitoring near H-Area seepage basins 


\section{References}

Aadland, R. K., P. A. Thayer, and A. D. Smits, 1992, Hydrostratigraphy of the Savannah River Site Region, South Carolina and Georgia, in Wallace Fallaw and Van Price, eds: Geological Investigations of the Central Savannah River Area, South Carolina and Georgia, Carolina Geological Field Trip Guide Book, November 13-15, 1992, South Carolina Geological Survey, Harbison Forest Road, Columbia, SC 29210-40898, pp. CSG-B-X-1 to 6.

Bledsoe, H. W., 1988, SRP Baseline Hydrogeologic Investigation - Phase III," DPST-88-627, E. I. du Pont de Nemours \& Co., Savannah River Laboratory, Aiken, SC.

Carlton, W. H., L. R. Bauer, A. G. Evans, L. A. Geary, C. E. Murphy, Jr., J. R. Pinder, and R. N. Strom, 1992, Cesium in the Savannah River Site Environment, WSRC-RP-92-250, Westinghouse Savannah River Company, Aiken, SC.

Christensen, E. J. and D. E. Gordon, 1983, Technical Summary of Groundwater Quality Protection Program at Savannah River Plant, Volume 1, DPST83-829, F. I. du Pont de Nemours \& Co., Savannah River Laboratory, Aiken, SC.

Domenico, P. A. and F. W. Schwartz, 1990, Physical and Chemical Hydrogeology, New York, John Wiley \& Sons.

Drever, J. I., 1988, The Geochemistry of Natural Waters, Englewood Cliffs, NJ., Prentice Hall.

Garrels, R. M., and C. L. Christ, 1965, Solutions, Minerals, and Equilibria. New York, Harper \& Row.

Gohn, G. S. 1988, Late Mesozoic and Early Cenozoic Geology of the Atlantic Coastal Plains; North Carolina to Florida, The Geology of North America, Boulder, CO., Geologic Society of America, pp. 107. 130.

IBP, 1981, Dynamic Properties of Forest Ecosystems, International Biological Program 23, D. E. Reichle, ed., Cambridge University Press, pp. 683.
Killin, T. H., et al., 1985, Environmental Information Document - H-Area Seepage Basins, DPST-85-706, E. I. du Pont de Nemours \& Co., Savannah River Laboratory, Aiken, SC.

Marine, I. W., 1974, Geohydrology of Buried Triassic Basin at Savannah River Plant, South Carolina, American Association of Petroleum Geologists Bulletin 58:1825-1837.

McIntyre, P. F. 1988, Sorption Properties of Carbon14 on Savannah River Plant Soil, DPST-88-900, E. I. du Pont de Nemours \& Co., Savannah River Laboratory, Aiken, SC.

Murphy, Jr., C. E., 1985, Carbon Dioxide Exchange and Growth of a Pine Plantation, Forest Ecology and Management, 11:203-224.

NCRP, 1985, Carbon-14 in the Environment, NCRP Report 81, National Council on Radiation Protection and Measurement, Bethesda, MD.

Ralston, 1974, Annual Primary Productivity in a Loblolly Pine Plantation, IUFRO Biomass Studies, H. E. Young, ed., University of Maine, Orono, p. 532.

Reichert, S. O., 1968. Geology Plays an Important Role in Radioactive Waste Management, Mining Engineering (September): 98-103.

Siple, G. E., 1967, Geology and Groundwater of the Savannah River Plant and Vicinity, South Carolina, U. S. Geological Survey, Washington, DC.

Stone, J. A. and E. J. Christensen, 1983, Technical Summary of Groundwater Quality Protection Program at Savannah River Plant, Volume II Radioactive Waste, DPST-83-829, E. I. du Pont de Nemours \& Co., Savannah River Laboratory, Aiken, SC.

UNSCEAR, 1982, Ionizing Radiation: Siurces and Biological Effects, United Nations Scientific Committee on the Effects of Atomic Radiction 1982 Report to the General Assembly, with annexes, United Nations Publication No. E.82.IX.8, C6300P. 


\section{Chapter 5. Assessment of Dose/Risk from the Savannah River Site Radiocarbon Releases}

This chapter describes the health impacts associated with exposure to radiocarbon. The methodology used to produce dose estimates is presented. The results of a dose assessment for radiocarbon releases during the 1954-1989 period are discussed. 
This page intentionally left blank. 


\section{Relationship of Dose to Risk and Health Effects}

\section{Ionizing Radiation}

Ionizing radiation is radiation that has sufficient energy to remove electrons from the atoms through which it passes. The interaction of ionizing radiation witt biological systems can induce a series of themical reactions that can cause permanent changes in the genetic material of cells. These changt $s$ (mutations) may cause abnormal functioning within the cell or lead to cell death.

The nature of radiation-induced cellular changes depends on the magnitude of the dose and the rate at which it is received. For the low doses and dose rates encountered in the environment from SRS releases, the most significant effect is cancer induction. This is believed to be a stochastic effect (i.e., an increase in dose increases the probability of the effect, but the severity of the effect is independent of dose).

A characteristic of stochastic risks is the absence of a threshold. In other words, it is conceivable that any dose of radiation, no matter how small, might give rise to a cancer. On the other hand, there is no way to be certain that a given dose, no matter how large, will cause a cancer in an individual.

\section{Cancer Risk Estimates}

The most comprehensive estimate of cancer induction by exposure to ionizing radiation come from studies of the survivors at Hiroshima and Nagasaki. Less definitive studies include those of medical patients exposed to therapeutic and diagnostic radiation. Studies of laboratory animals have increased the understanding of dose-effect relationships. The International Commission on Radiological Protection (ICRP) has evaluated all these studies and concluded that the best estimate of lifetime risk of fatal cancer for members of the general population is approximately 500 cases per $1,000,000$ person-rem (ICRP, 1991). This is equivalent to one case per 2000 person-rem.

\section{Radiocarbon Exposure and Dose to Man}

\section{Distribution and Retention of Carbon in the Human Body}

Carbon is an element essential to life on earth. The average human contains about $16,000 \mathrm{~g}$ of carbon and consumes $300 \mathrm{~g} / \mathrm{d}$ of dietary carbon (ICRP, 1975). Most of the ingested carbon is metabolized to $\mathrm{CO}_{2}$ and eliminated rapidly from the body. A small portion is retained in the body as carbohydrate, protein, or fat. ${ }^{14} \mathrm{C}$ is biologically identical to stable ${ }^{12} \mathrm{C}$ and is incorporated into all organs of the body. For dosimetric purposes, the ICRP has suggested a conservative value of $\mathbf{4 0}$ days for the biological half time. Virtually all of the inspired $\mathrm{CO}_{2}(4 \mathrm{~g} / \mathrm{d}$ is immediately respired, but about $1 \%$ is retained in the body because of exchange with existing carbon compounds (NCRP, 1985).

\section{Radiocarbon Dosimetry}

The U.S. Department of Energy (DOE) issued internal dose conversion factors in 1988, to ensure that doses are calculated in a consistent manner at all DCE facilities (DOE, 1988). The factors are based on ICRP recommendations (ICRP, 1979). These dose factors are used to calculate all the doses reported in this document in conjunction with the models described in the subsection on model: of radiocarbon transport and dose.

Future changes are anticipated in the dose calculation methodology. The ICRP (ICRP, 1989) has issued age-specific dose factors for ingestion of some of the more common isotopes and is developing agespecific dose factors for inhalation of radioisotopes. 


\section{Models of Radiocarbon Transport and Dose}

With the exception of tritium, most of the radioactive material released from SRS has such low concentration in the offsite environment that it is not detectable by conventional monitoring techniques. Therefore, radiation doses to offsite individuals and populations are calculated with mathematical models. These models use known transport mechanisms for atmospheric and liquid releases and known major pathways of exposure to man. Modeled atmospheric and aqueous dispersion are periodically verified using environmental tritium measurements (tritium is released during normal SRS operations).

The first models used at SRS for calculating offsite doses were developed by the Savannah River Laboratory (Cooper, 1975). These models, MREM (atmospheric releases) and RIVDOSE (liquid releases), were first used in 1972. In 1982, MREM and RIVDOSE were replaced with the more technologically advanced models now in use.

\section{Atmospheric Releases}

SRS annual offsite doses are calculated with the transport and dose models developed for the commercial nuclear industry (NRC, 1977a and NRC, 1977b). The models are implemented at SRS in the following computer programs:

- MAXIGASP: calculates maximum and average doses to offsite individuals

- POPGASP: calculates offsite population collective dose

MAXIGASP and POPGASP are SRTC-modified versions of the Nuclear Regulatory Commission (NRC) programs XOQDOQ (Sagendorf et al., 1982) and GASPAR (Eckerman et al., 1980). The modifications were made to meet the requirements for input of physical and biological data specific to SRS. The basic calculations in the XOQDOQ and GASPAR programs have not been modified.

$X O Q D O Q$ has undergone a comprehensive review in association with the Westinghouse Savannah River Company (WSRC) quality assurance requirements for software (Bauer, 1991).

\section{Modeling Atmospheric Dispersion of Radioactive Releases}

The routine atmospheric transport of radioactive materials from SRS is evaluated on the basis of metcorological conditions measured continuously at seven onsite towers. The towers relay wind speed, direction, and atmospheric stability information at 1.5 -second intervals to the SRTC via the WIND (Weather INformation and Display) system. A database of this information containing the 60-min average values for the 1982-1986 period is accessed by dispersion codes to estimate downwind concentrations of released radionuclides.

Offsite doses have been calculated using H-Area meteorology and assuming the releases occurred at the geographic center of the site. It has been demonstrated that using data from one of the other onsite meteorological towers has little effect on the maximum individual dose and no effect on the 50-mile population dose (Hamby and Parker, 1991).

The dispersion of an atmospheric release from SRS is modeled using $\mathrm{XOQDOQ}$ which computes concentration in the plume as a function of downwind distance and compass sector. At the user's option, the plume can be depleted by dry deposition and/or radioactive decay. Also at the user's option, plume concentration can be reduced by taking into account the upward displacement of the effluent resulting from thermal buoyancy and/or momentum effects. This option is not used at SRS (i.e., no credit is taken for plume rise).

The plume concentration information generated by XOQDOQ is used by the dose modeling program GASPAR to estimate doses to offsite individuals and populations. GASPAR estimates doses from a number of pathways, which are illustrated in a general sense in Figure 5.1.

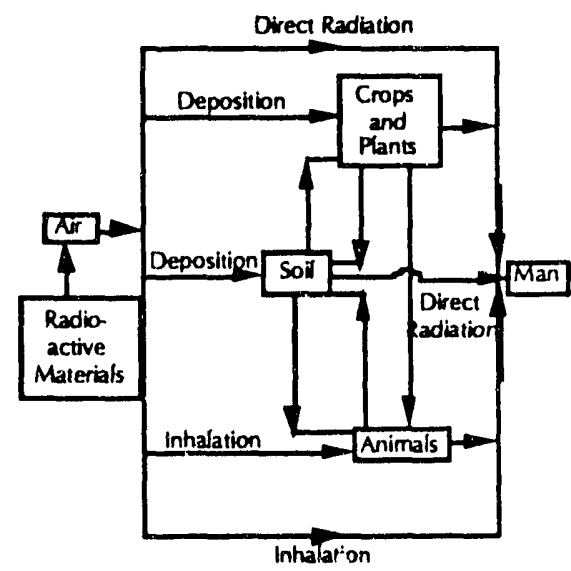

Figure 5.1. Simplified pathways between radioactive materials released to the atmosphere and man 
The doses estimated by GASPAR are reported on a pathway-specific basis as follows:

- Plume - external dose from radioactive materials suspended in the atmosphere

- Ground - extemal dose from radioactive materials deposited on the ground

- Inhalation - intemal dose from inhalation of radioactive materials present in the plume

- Vegetation - internal dose from cossumption of contaminated crops

- Milk - internal dose from milk produced in a contaminated area

- Meat - internal dose from consumption of meat produced in a contaminated area.

\section{MAXIGASP}

The calculations required by $X O Q D O Q$ and GASPAR to estimate maximum and average individual doses are performed at the SRS using the computer program MAXIGASP. MAXIGASP calculates annual average ground-level air concentrations and 50-yr committed doses at a number of points along the site boundary in each of 16 compass sectors.

The main outputs from the program are the maximum dose equivalents to an individual along the SRS perimeter. The maximally exposed individual is assumed to reside continuously at the location of highest exposure and to have living and eating habits which maximize his dose. These assumptions provide a ceiling on doses from atmospheric releases, as no such individual is believed to exist.

The site specific parameters (Hamby, 1991) used to calculate doses with MAXIGASP are presented in Table 5-1.

\section{POPGASP}

The calculations required by XOQDOQ and GASPAR to estimate population doses from atmospheric releases are performed at the SRS using POPGASP. This program calculates annual average ground-level air concentrations and annual doses for each of 160 regions (16 wind direction sectors at 10 distances per sector) within an 80-kilometer radius of the release location.
In addition to compass-sector-specific meteorological information, POPGASP uses sector-specific data on population distribution and composition. Comparable data on milk, meat, and vegetable production and consumption are also used in the code. These databases are quite extensive and are available for review in the annual SRS Environmental Report. With respect to the human parameters used in POPGASP, the key values are shown in Table 5-1.

Table 5-1. Site-specific parameters for atmospheric releases

\section{Population Groun}

50-mile radius

555,100

Exposure Pathray

Maximum Individual

Inhalation $\left(\mathrm{m}^{3} / \mathrm{yr}\right)$

8000

Ingestion

Cow's milk (L/yr)

Meat (kg/yr)

Leafy vegetables (kg/yr)

Fruits, grains, and other

leafy vegetables $(\mathrm{kg} / \mathrm{yr})$

External exposure

Transmission factor for

shielding from buildings

\section{Exposure Pathway}

General Population (POPGASP)

Inhalation $\left(m^{3} / y r\right)$

8000

Ingestion

Cow's milk (L/yr)

Meat $(\mathrm{kg} / \mathrm{yr})$

Leafy vegetables $(\mathrm{kg} / \mathrm{yr})$

Fruits, grains, and other

vegetables $(\mathrm{kg} / \mathrm{yr})$

External exposure Transmission factor for shielding from buildings 


\section{Validation of Transport Models Using Monitoring Data}

\section{Atmospheric Releases}

The radionuclide concentrations predicted by XOQDOQ are compared routinely with measured values of tritium concentration in air to evaluate the performance of the code. (Tritium is the only radionuclide released by the SRS that can be routinely detected offsite using conventional measuring techniques.) Predicted values tend to exceed observed values, but not to a degree that would indicate an excessively conservative approach.

Other comparisons of predicted and measured concentration have been made (Marter, 1984) and have exhibited similar results. The available data suggests that the calculated concentration of tritium in air generally is a conservative estimate of actual offsite values.

\section{Impact of the Savannah River Site Radiocarbon Releases on the Offsite Population}

\section{Introduction}

The computer codes MAXIGASP and POPGASP have been used to calculate effective dose equivalents that theoretically have been received by segments of the offsite population from radiocarbon exposure during site operations. The results are shown in Table 5-2 for doses attributable to atmospheric releases. Liquid radiocarbon releases to site streams are unlikely and have never been measured.

\section{Doses from Atmospheric Releases}

As shown in Table 5-2, the largest annual effective dose equivalent (EDE) theoretically received by an adult occurred in the 1959-1963 time period. The EDE from ${ }^{14} \mathrm{C}$ to the "maximum" adult at the site perimeter was $0.05 \mathrm{mrem}$.

"Maximum" individuals are hypothetical persons who lived at the SRS boundary and subsisted on diets of locally produced milk, meat, and vegetables. No such individuals are known to exist. Nevertheless, if one examines the case of the maximally exposed adult individual living continuously at the site perimeter throughout the 1954-1989 period, the cumulative EDE from atmospheric release of ${ }^{14} \mathrm{C}$ has been estimated as $1.1 \mathrm{mrem}$ (Table 5-2). This value is the upper-bounding case and would make a minor contribution to the overall dose received during that time period.
A person living in the Central Savannah River Area (CSRA) would have received an effective dose of approximately 10,620 mrem from exposure to natural sources of radioactivity and an additional $2340 \mathrm{mrem}$ from medical practices and various consumer products during the 36-year period (Cummins et al., 1990). Therefore, the cumulative dose contribution to this individual from SRS atmospheric radiocarbon release can be estimated as $0.008 \%$.

Because the contribution of SRS radiocarbon release to any one individual's total radiation dose is so small, it is necessary to pool the radiation exposure from a given population if an assessment of potential health impact is desired. The population dose within an 80 -kilometer radius is the figure of merit frequently used to make such an assessment.

The population doses reported in Table 5-2 are based on 1980 census data $(555,100$ people within $80 \mathrm{~km}$ ) and current meteorological and dose factor data. If it is assumed that this population has lived in the SRS vicinity throughout the period of site operation, th.? total collective effective dose received by that population through 1989 would be 33 person-rem.

The impact associated with this collective dose are quite small. The impact estimate using the ICRP factor for the number of excess fatal cancers potentially induced by a collective dose of 33 person-rem is 0.016 . Conversely, in that same population, at the current fatal cancer frequency of $16 \%$ (EPA, 1989), 
Table 5-2. Orrsite Doses from Atmospheric Releases of ${ }^{14} \mathrm{C}$

\begin{tabular}{|c|c|c|c|c|}
\hline \multirow[b]{3}{*}{ Year } & \multirow{3}{*}{$\begin{array}{c}\text { Release }^{(0)} \\
(\mathrm{Ci} / \mathrm{yr})\end{array}$} & \multicolumn{2}{|c|}{ Site Perimeter CEDE (b) } & \multirow{3}{*}{$\begin{array}{c}\begin{array}{c}E D C \\
(c)\end{array} \\
\text { (person-rem) } \\
\text { (80-km Pop) }\end{array}$} \\
\hline & & (mrem) & (mrem) & \\
\hline & & (Max Ind) & (Average Ind) & \\
\hline 1955 & $8.30 \times 10$ & 0.031 & 0.021 & 0.91 \\
\hline 1956 & $8.40 \times 10$ & 0.031 & 0.021 & 0.92 \\
\hline 1957 & $8.40 \times 10$ & 0.031 & 0.021 & 0.92 \\
\hline 1958 & $8.40 \times 10$ & 0.031 & 0.021 & 0.92 \\
\hline 1959 & $1.38 \times 10^{2}$ & 0.051 & 0.035 & 1.52 \\
\hline 1960 & $1.38 \times 10^{2}$ & 0.051 & 0.035 & 1.52 \\
\hline 1961 & $1.38 \times 10^{2}$ & 0.051 & 0.035 & 1.52 \\
\hline 1962 & $1.38 \times 10^{2}$ & 0.051 & 0.035 & 1.52 \\
\hline 1963 & $1.38 \times 10^{2}$ & 0.051 & 0.035 & 1.52 \\
\hline 1964 & $1.10 \times 10^{2}$ & 0.041 & 0.028 & 1.21 \\
\hline 1965 & $1.10 \times 10^{2}$ & 0.041 & 0.028 & 1.21 \\
\hline 1966 & $1.10 \times 10^{2}$ & 0.041 & 0.028 & 1.21 \\
\hline 1967 & $1.10 \times 10^{2}$ & 0.041 & 0.028 & 1.21 \\
\hline 1968 & $8.70 \times 10$ & 0.032 & 0.022 & 0.96 \\
\hline 1969 & $8.70 \times 10$ & 0.032 & 0.022 & 0.96 \\
\hline 1970 & $8.80 \times 10$ & 0.033 & 0.022 & 0.97 \\
\hline 1971 & $8.70 \times 10$ & 0.032 & 0.022 & 0.96 \\
\hline 1972 & $8.70 \times 10$ & 0.032 & 0.022 & 0.96 \\
\hline 1973 & $8.70 \times 10$ & 0.032 & 0.022 & 0.96 \\
\hline 1974 & $8.01 \times 10$ & 0.030 & 0.020 & 0.88 \\
\hline 1975 & $6.60 \times 10$ & 0.025 & 0.017 & 0.73 \\
\hline 1976 & $6.90 \times 10$ & 0.026 & 0.017 & 0.76 \\
\hline 1977 & $6.30 \times 10$ & 0.023 & 0.016 & 0.69 \\
\hline 1978 & $5.70 \times 10$ & 0.021 & 0.014 & 0.63 \\
\hline 1979 & $5.60 \times 10$ & 0.021 & 0.014 & 0.62 \\
\hline 1980 & $6.60 \times 10$ & 0.025 & 0.017 & 0.73 \\
\hline 1981 & $6.90 \times 10$ & 0.026 & 0.017 & 0.76 \\
\hline 1982 & $8.00 \times 10$ & 0.030 & 0.020 & 0.88 \\
\hline 1983 & $9.00 \times 10$ & 0.034 & 0.023 & 0.99 \\
\hline 1984 & $8.30 \times 10$ & 0.031 & 0.021 & 0.91 \\
\hline 1985 & $7.60 \times 10$ & 0.028 & 0.019 & 0.84 \\
\hline 1986 & $4.57 \times 10$ & 0.017 & 0.011 & 0.50 \\
\hline 1987 & $4.10 \times 10$ & 0.015 & 0.010 & 0.45 \\
\hline 1988 & $2.40 \times 10$ & 0.009 & 0.006 & 0.26 \\
\hline 1989 & $1.80 \times 10$ & 0.007 & 0.004 & 0.20 \\
\hline $\boldsymbol{\Sigma}$ & $2.97 \times 10^{3}$ & 1.108 & 0.749 & 32.69 \\
\hline
\end{tabular}

(a) Release data from Cummins, Hetrick, and Martin 1991.

(b) CEDE = committed effective dose equivalent.

(c) $\mathrm{EDC}=$ environmental dose commitment. 
there will be about 90,000 fatal cancers from all other causes. Therefore, it is impossible to demonstrate that a relationship exists between any of the cancer deaths occurring in this population and the release of radiocarbon to the atmosphere from SRS.

\section{Doses from Liquid Releases}

Since there are no known liquid releases of ${ }^{14} \mathrm{C}$ to streams, the dose from this pathway is zero.

\section{Comparisons of Radiocarbon Doses Near the Savannah River Site with Applicable Regulations}

\section{Atmospheric Releases}

The highest hypothetical annual effective dose received by the maximally exposed individual due to atmospheric release of radiocarbon from SRS was 0.05 mrem (Table 5-2). The current EPA annual limit on doses to members of the public due to atmospheric release is $10 \mathrm{mrem}$.

\section{Liquid Releases}

Radiocarbon doses from drinking water sources are evaluated based on the EPA annual drinking water standard of $4 \mathrm{mrem}$. Since there are no known releases of ${ }^{14} \mathrm{C}$ to streams, radiocarbon did not contribute any dose.

\section{Summary of Dosimetric Impacts}

The overall radiological impact of SRS radiocarbon releases (1954-1989) on the offsite maximum individual can be characterized by a total dose of $1.1 \mathrm{mrem}$. During this same period, however, such an individual received a dose of approximately 12,960 mrem from other sources of ionizing radiation present in the environment.

The impact of SRS radiocarbon releases on offsite populations also has been evaluated. The total collective dose from atmospheric radiocarbon releases (1954-1989) is estimated as 33 person-rem distributed among 555,100 individuals.

Radiocarbon releases from the SRS present a negligible impact to the offsite environment and the population it supports.

\section{References}

Bauer, L. R., 1991, Modeling Chronic Atmospheric Releases at the SRS: Evaluation and Verification of $X O Q D O Q(U)$, WSRC-RP-91-320, Westinghouse Savannah River Company, Aiken, SC.

Cooper, R. E., 1975, Computer Programs at SRL to Evaluate Environmental Effects of SRP Operations and Postulated Accidental Releases, DPST-75-384, Savannah River Laboratory, Aiken, SC.

Cummins, C. L., D. K. Martin, and J. L. Todd, 1990, Savannah River Site Environmental Report for 1989.
WSRC-IM-90-60, Westinghouse Savannah River Company, Aiken, SC, p xv.

Cummins, C. L., C. S. Hetrick, and D.K. Martin, 1991, Radioactive Releases at the Savannah River Site 1954-1989, WSRC-RP-91-684, Westinghouse Savannah River Company, Aiken, SC.

DOE (U. S. Department of Energy), 1988, Internal Dose Conversion Factors for Calculation of Dose to the Public, DOE/EH-0071, Washington, D.C. 
Eckerman, K. F., F. J. Congel, A. K. Roecklein, and W. J. Pasciak, 1980, User's Guide to GASPAR Code, NUREG-0597, U. S. Nuclear Regulatory Commission, Washington, DC.

EPA, 1989, 40 CFR Part 61, National Emission Standards for Hazardous Air Pollutants; Regulation of Radionuclides; Final Rule and Notice of Reconsideration, Federal Register, Vol. 54, No. 240.

Hamby, D. M., 1991, Land and Water Use Characteristics in the Vicinity of the Savannah River Site (U), WSRC-RP-91-17, Westinghouse Savannah River Company, Aiken, SC.

Hamby, D. M., and M. J. Parker, 1991, Gaussian Dispersion and Dosimetric Modeling Sensitivity 10 Area-Specific 1982-1986 Meteorological Data Collected at the Savannah River Site (U), WSRCRP-91-909, Westinghouse Savannah River Company, Aiken, SC.

ICRP (International Commission on Radiological Protection), 1975, Report of the Task Group on Reference Man, ICRP Publication 23, Pergamon Press, New York, NY.

ICRP, 1979, Limits for Intake of Radionuclides by Workers, ICRP Publication 30, Part 1, Annals of the ICRP.

ICRP, 1989, Age-Dependent Doses to Members of the Public from Radionuclides, ICRP Publication 56, Annuals of the ICRP.
ICRP, 1991, Risks Associated with lonizing Radiations, Vol. 22, No. 1, Annals of the ICRP.

Marter, W. L., 1984, Environmental Dosimetry for Normal Operations at SRP, DPST-83-270, Rev. 1, Savannah River Laboratory, Aiken, SC.

NCRP (National Council on Radiation Protection and Measurement), 1985, Carbon-14 in the Environment, NCRP Report No. 81, Bethesda, MD.

NRC (U. S. Nuclear Regulatory Commission), 1977a, Methods for Estimating Atmospheric Transport and Dispersion of Gaseous Effluents in Routine Releases from Light-Water-Cooled Reactors, Regulatory Guide 1.111, Rev. 1, Washington, DC.

NRC, 1977b, Calculation of Annual Doses to Man from Routine Releases of Reactor Effluents for the Purpose of Evaluating Compliance with 10 CFR Parl 50, Appendix I, Regulatory Guide 1.109, Rev. 1, Washington, DC.

Sagendorf, J. F., J. T. Goll, and W. F. Sandusky, 1982, XOQDOQ: Computer Program for the Meteorological Evaluation of Routine Effluent Releases at Nuclear Power Stations, NUREG/CR2919, U.S. Nuclear Regulatory Commission, Washington, DC. 
This page intentionally left blank. 

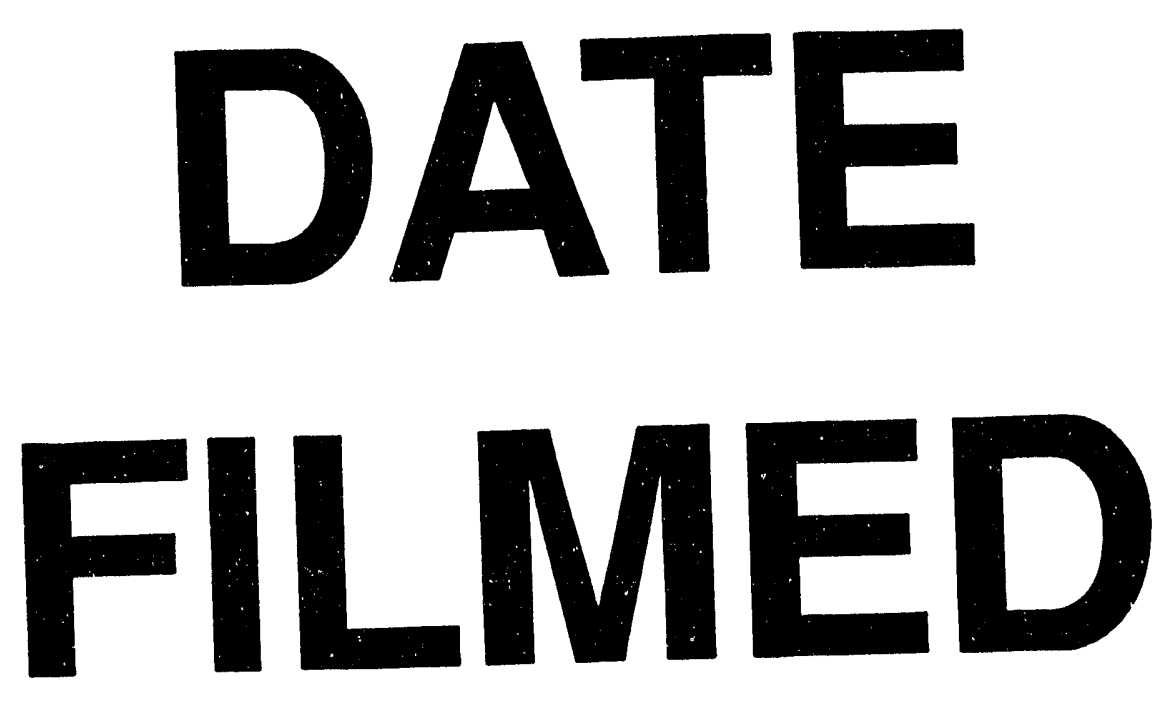

$8 / 4 / 93$
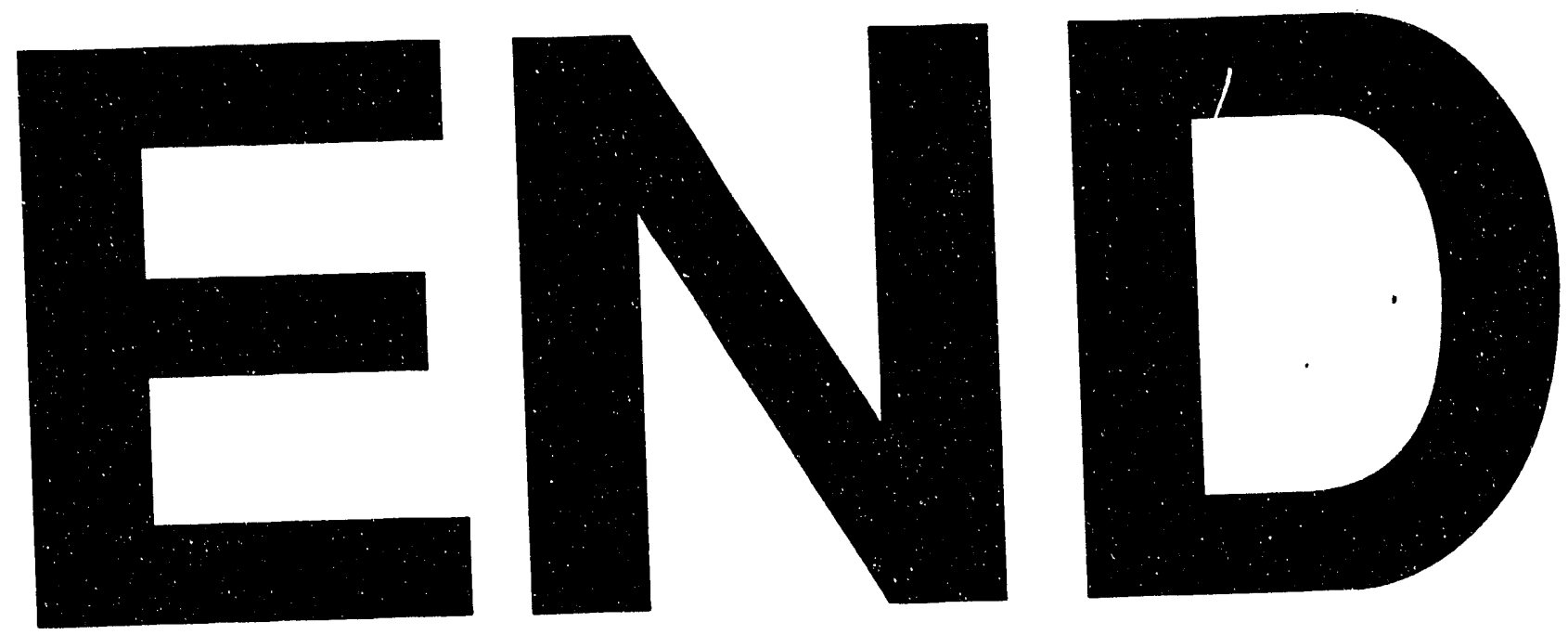


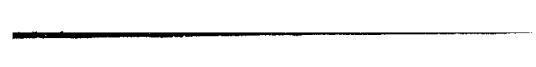

